\title{
El personal de la Administración Local y el nuevo marco regulador de la función pública*
}

\author{
Leopoldo Tolivar Alas \\ Catedrático de Derecho Administrativo. \\ Universidad de Oviedo
}

Sumario: I. SOBRE LA TERMINOLOGÍA: ¿OBJETIVIDAD O DESHUMANIZACIÓN?.II. EL CONCEPTO DE FUNCIONARIO Y EL ESTATUTO BÁSICO. 1. Elementos definidores del funcionario en la normativa básica. 2. Singularidad, menor, en la función pública local. 3. Funcionarios y estructuras organizativas locales.-III. RECORDATORIO SOBRE LO BÁSICO EN EL ÁMBITO LOCAL. 1. Situaciones previas a la Ley 7/2007: principios generales y admisión de excepciones. 2. El EBEP en el contexto de los nuevos Estatutos de Autonomía. 3. Alusión al personal laboral y al de entidades no sometidas al Derecho Administrativo. 4. Alteración de proporciones en los distintos niveles territoriales del empleo público y movilidad. - IV. ORÍGENES Y EVOLUCIÓN PROPIA DE LA FUNCIÓN PÚBLICA LOCAL. - V. LO BÁSICO EN LA FUNCIÓN PÚBLICA LOCAL: UNA REGULACIÓN DISPERSA. 1. Administración en sentido estricto y sector público local. 2. Ordenación estatutaria y peculiaridades locales. - VI. COORDINACIÓN, COLABORACIÓN Y COOPERACIÓN. - VII. ALGUNAS NOVEDADES TRAIIDAS POR EL EBEP A LA FUNCIÓN PÚBLICA LOCAL. 1. Estatuto y normativa básica preexistente. 2. Aplicación directa y aplicación inmediata de la nueva legislación a las entidades locales. 3. Sobre los funcionarios con habilitación de carácter estatal.

\section{SOBRE LA TERMINOLOGÍA: ¿OBJETIVIDAD O DESHUMANIZACIÓN?}

Aún cuando esta observación sea obvia, ¿cuántas veces en las leyes, en los Decretos de Transferencia, en las sentencias o en los manuales no habremos leído la expresión «medios materiales y personales», con la que se nos coloca a los empleados públicos al mismo nivel que un mueble de oficina ${ }^{1}$ ? La función pública, ¿es sólo un medio para alcanzar un fin o es algo en sí misma? ¿Estamos cosificados los funcionarios? Y en el ámbito local, ¿qué papel instrumental ha de jugar el personal estatutario o, en su caso, el laboral?

Es cierto que, por mandato constitucional, la Administración debe servir con objetividad los intereses generales, con sometimiento pleno a la Ley y al Derecho $^{2}$ y que esa proscripción de intereses particulares de funcionarios se manifiesta en la imposición de «garantías para la imparcialidad en el ejerci-

\footnotetext{
* El presente artículo se corresponde sustancialmente con la ponencia expuesta en las Jornadas de la Federación Española de Municipios y Provincias (FEMP) sobre «La Administración Local ante los retos de los desarrollos Estatutarios», celebradas en Madrid del 1 al 3 de diciembre de 2008.

1 Hasta existe, en el Ministerio de Justicia por ejemplo, alguna Subdirección General de Medios Personales.

2 Art. 103.1 CE.
} 
cio de sus funciones» ${ }^{3}$, comenzando por las reglas de abstención y recusación ${ }^{4}$ que también afectan a las autoridades o cargos públicos. Esos fines vinculados a la utilidad pública o al interés social de la colectividad justifican la actividad de la Administración y el apartamiento de los mismos es tan fiscalizable por los Tribunales como la comisión de una ilegalidad ${ }^{5}$.

Los empleados públicos, en suma, ¿no son también un fin para el Derecho? La materia de organización siempre se ha visto, quizá por un prejuicio doctrinal de origen germánico, como una técnica variable y poco consistente al lado de la actividad de las Administraciones, más científica y sólida y menos contingente. Se suele señalar que al particular - y es cierto - le da lo mismo que haya quince ministerios o veinte o que tal consejería o concejalía se llame de una manera o de otra. Eso tiene poco de jurídico y raramente puede afectar a sus derechos e intereses. Los cambios organizativos buscan, utópicamente, la racionalidad, la economía, la eficacia, la eficiencia... lo que está muy bien y permite expresar políticas propias de cada opción política ganadora de unos comicios en los distintos niveles territoriales. Pero la política de personal, como juristas más sensibles vienen denunciando, no puede meterse en el mismo saco que el número de rótulos, de despachos, de mesas o de ordenadores. Los funcionarios son el elemento vivo, el factor humano, de una Administración imparcial pero no despersonalizada ${ }^{6}$. La robótica o el acceso electrónico de los ciudadanos a los servicios públicos ${ }^{7}$ no elimina al funcionariado; al revés: lo cualifica con la exigencia de nuevos conocimientos y responsabilidades porque tramitación telemática no equivale a procedimiento anónimo e irresponsable.

Que los funcionarios no son sólo una herramienta, un recurso humano ${ }^{8}$ para la satisfacción de un fin se desprende de distintos preceptos constitucionales y

\footnotetext{
3 Art. 103.3 CE, a propósito de la regulación por ley del estatuto de los funcionarios. En tal sentido, véanse los artículos 1.3 , a) y e); 53.2 y 5 y 95.2.h) y j) de la Ley 7/2007, de 12 de abril, aprobatoria del Estatuto Básico del Empleado Público.
}

4 Artículos 28 y 29 de la Ley 30/1992, de 26 de noviembre, de Régimen Jurídico de las Administraciones Públicas y del Procedimiento Administrativo Común.

5 Art. 106.1 CE.

6 Los ciudadanos tienen derecho a ser tratados con respeto y deferencia por autoridades y funcionarios que habrán de facilitarles el ejercicio de sus derechos y el cumplimiento de sus obligaciones (art. 35.i de la Ley 30/1992 de 26 de noviembre). La grave falta de consideración con los administrados es, en el ámbito estatal, una falta grave, en tanto que la mera incorrección con el público es una falta leve (arts. 7.1.o y 8.c del Real Decreto 33/1986, de 10 de enero, por el que se aprueba el Reglamento de Régimen Disciplinario de los Funcionarios de la Administración del Estado; disposición supletoria, según su artículo 3, para las Administraciones locales y autonómicas).

7 Ley 11/2007, de 22 de junio. Su Disposición Adicional Segunda se refiere justamente a la formación de empleados públicos: «La Administración General del Estado promoverá la formación del personal a su servicio en la utilización de medios electrónicos para el desarrollo de las actividades propias de aquélla. En especial, los empleados públicos de la Administración General del Estado recibirán formación específica que garantice conocimientos actualizados de las condiciones de seguridad de la utilización de medios electrónicos en la actividad administrativa, así como de protección de los datos de carácter personal, respeto a la propiedad intelectual e industrial y gestión de la información».

8 Como se dice, por ejemplo, en el art. 85 bis. 2 e) de la LBRL en redacción dada por Ley 57/2003, de 16 de diciembre o en los arts. 69 a 72 del Estatuto Básico del Empleado Público, de 2007. 
legales. Su incardinación en el seno de la Administración los coloca en una relación de especial sujeción ${ }^{9}$ con aquélla, en la que se crean o limitan derechos y se imponen obligaciones, alterándose algún estándar general como puede ser el llamado «deber de soportar», trascendental de cara a la exigencia de responsabilidad patrimonial a los poderes públicos ${ }^{10}$. Es claro que un sujeto con derechos laborales frente a la Administración, profesionales y retributivos, inamovible, con un régimen singular, a veces restrictivo, de ejercicio de derechos fundamentales no es un mero «medio» estático, mutable e inanimado. No es un objeto para el derecho sino un sujeto de derechos y deberes.

Es también el funcionario, como se acaba de decir, un trabajador. No se trata de que, a través del empleo público, las Administraciones satisfagan el desiderátum del principio rector contenido en el artículo 35.1 de la Constitución Española (CE). Mal está la inflación funcionarial en las Administraciones, cuestión que se observa en numerosos países de la Unión Europea, pero esa crítica, cuando proceda, no puede convertirse en un estigma para el trabajo público tan digno y, si cabe, más necesario que el que se desarrolla en ámbitos privados. Por tanto, sin que la finalidad, como se apunta, deba ser emplear cuantitativa e indiscriminadamente, sino en función de las necesidades reales, es evidente que a las Administraciones les atañen el respeto al derecho al trabajo, a la promoción a través del mismo, al abono de las retribuciones suficientes para satisfacer las necesidades del empleado y su familia y a la no discriminación por razón de sexo. Mandatos constitucionales que se complementan con desarrollos legales y Convenios internacionales en los que España es parte. Las Administraciones, por tanto, han de ser escrupulosas a la hora de ordenar esos recursos humanos, en nada comparables con unos medios materiales que ni tienen que promocionar, ni ser sustento de nada, ni son titulares de derechos igualitarios.

En fin, los empleados públicos son profesionales ${ }^{11}$, que han ejercido el derecho constitucional a la libre elección de una actividad especializada ${ }^{12}$ y retribuida. Profesionales a los que las Administraciones, personas jurídicas al cabo, encomiendan el servicio a los ciudadanos convirtiéndose así en sus interlocutores identificados y responsables ${ }^{13}$. El error de una máquina, el manido «fallo informático», podrá, si causa un daño indemnizable, ser objeto de la responsabilidad objetiva de la Administración. Pero si media dolo, culpa o negligencia grave de un funcionario - o autoridad-, la Administración exigirá, por vía de

\footnotetext{
9 Véase Ricardo GARCÍA MACHO, Las relaciones de especial sujeción en la Constitución española, Tecnos, Madrid, 1992, págs. 208 y sigs. e Iñaki LASAGABASTER HERRARTE, Las relaciones de especial sujeción, Civitas-IVAP, Madrid, 1994, págs. 404 y sigs.

10 Art. 141.1 de la Ley 30/1992.

11 Art. 1.3.e) del Estatuto Básico del Empleado Público.

12 Cuestión que hemos abordado en el trabajo «La configuración constitucional del derecho a la libre elección de profesión u oficio», en S. MARTÍN-RETORTILLO (coordinador) y otros, Estudios sobre la Constitución Española. Homenaje al Prof. García de Enterría, Civitas, Madrid, 1991, Vol. II, págs. 1337-1370.
}

13 Art. 35. b) y j) de la Ley 30/1992, de 26 de noviembre. 
repetición, el correspondiente quántum al empleado público ${ }^{14}$ quien, eventualmente, podría incurrir también en la responsabilidad derivada de delito, existiendo una amplia tipología criminal vinculada al empleo público ${ }^{15}$.

En definitiva, las personas que encarnan el empleo público son, para el Derecho, materia sensible y algo más que materia. Hora es, por tanto, en estos tiempos tan cuidadosos del lenguaje no peyorativo o discriminatorio, de dignificar terminológicamente a los funcionarios puesto que nadie llama, ni coloquial ni técnicamente, medios o recursos personales a ministros, consejeros o alcaldes. Y ellos son, en virtud del principio democrático, más variables en la estructura administrativa que los funcionarios inamovibles, auténtico sedimento del funcionamiento regular y continuo de los servicios públicos. La sensibilidad de la temática funcionarial, como se ve, sí caló en los redactores de la Constitución que, no en balde, configuraron como derecho fundamental, susceptible de recurso de amparo, el acceso en condiciones de igualdad a funciones públicas (y cargos), «con los requisitos que señalen las leyes» (art. 23.2 CE).

\section{EL CONCEPTO DE FUNCIONARIO Y EL ESTATUTO BÁSICO}

\section{Elementos definidores del funcionario en la normativa básica}

No en balde, de una lectura conjunta de los artículos 8 y 9 del Estatuto Básico del Empleado Público (EBEP) ${ }^{16}$ puede colegirse que los funcionarios de carrera son aquellos empleados públicos que, en virtud de nombramiento legal están vinculados a una Administración Pública por una relación estatutaria regulada por el Derecho Administrativo para el desempeño de servicios profesionales retribuidos de carácter permanente prestados dentro de una actividad dirigida a la satisfacción de intereses generales predeterminados. A esta clase de personal, las leyes han de reservar en exclusiva el ejercicio de funciones que impliquen la participación directa o indirecta en el ejercicio de las potestades públicas o en la salvaguardia de los citados intereses generales de cada Administración. Parece, por cierto, un tanto exagerada la expresión «participación

\footnotetext{
14 Art. 145.2 de la Ley 30/1992.

15 Caso de la prevaricación, el cohecho, el abandono del servicio, la infidelidad en la custodia de documentos o su falseamiento, el tráfico de influencias, la malversación, etc. Véanse el art. 146 de la Ley 30/1992 y los artículos 404 a 445, entre otros, del Código Penal aprobado por Ley orgánica 10/1995, de 23 de noviembre.

16 Aprobado por Ley 7/2007, de 12 de abril. Para un análisis de los preceptos legales, véase la obra colectiva dirigida por Miguel SÁnchez Morón, Comentarios a la Ley del Estatuto Básico del Empleado Público, 2. ${ }^{\text {a }}$ edición, Lex Nova, Valladolid, 2008, 616 págs. Igualmente, desde un punto de vista más práctico, aunque de gran utilidad, puede consultarse la obra específicamente local de Eduardo CHALUD LiLlo y M. ${ }^{\text {del Mar }}$ Chalud Aguilera, La función pública local (adaptada a la Ley 7/2007, de 12 de abril del Estatuto Básico del Empleado Público, Ed. Bayer Hnos., Barcelona, 2007.
} 
directa o indirecta en el ejercicio de las potestades públicas», toda vez que, si es entendible con respecto a la potestad certificante o a la de dar fe pública, o la sancionadora, no deja de ser poco realista pensar que, ni indirectamente, puede el personal no estatutario cooperar en el ejercicio de la potestad expropiatoria - cuando el beneficiario puede ser un privado y participa en el procedimiento-, de la potestad planificadora - cuando hay planes de iniciativa privada, gestiones por compensación, etc.- o, incluso, de elaboración de ordenanzas, donde la participación es pieza fundamental. Obsérvese que el EBEP no habla de «resolución» o de «responsabilidad en la tramitación», sino de «participación directa o indirecta». Bien es cierto que, en el ámbito local, como luego veremos y ha advertido tempranamente SÁNCHEZ MORÓN, «la reserva de puestos de trabajo a funcionario públicos, establecida hoy en la Disposición Adicional 2. ${ }^{\text {a }}$ EBEP, es mucho más limitada» ${ }^{17}$. Y hablando de potestades, debemos recordar cómo el propio EBEP, en su artículo 57.1, exceptúa del libre acceso de los nacionales de Estados miembros de la Unión Europea al funcionariado español, los empleos «que directa o indirectamente impliquen una participación en el ejercicio del poder público» ${ }^{18}$.

No ha habido una evolución sustancial en el concepto y caracteres del funcionario desde la legislación de Funcionarios Civiles del Estado de 1964 (Decreto 315/1964, de 7 de febrero). Como ha señalado SÁNCHEZ MoRÓN, «con terminología que hoy puede parecer algo impropia pues confunde el sistema de empleo con la temporalidad de la relación, el artículo 3 de la LFCE distingue entre funcionarios de carrera y de empleo. Los primeros son los que con estatuto funcionarial ( $e$ en virtud de nombramiento legal»), «desempeñan servicios de carácter permanente, figuran en las correspondientes plantillas y perciben sueldos o asignaciones fijas con cargo a las consignaciones de personal de los Presupuestos - de la Administración correspondiente- (art. 4 de la citada Ley). Son, en consecuencia, los funcionarios que podríamos llamar fijos ${ }^{19}$. Y ello aunque se recluten, en virtud del sistema de empleo ${ }^{20}$, para desempeñar una plaza singular, no escalafonada.

Por su parte, ENTRENA CUESTA viene advirtiendo que «el concepto de funcionario público es uno de los más imprecisos de cuantos se manejan por la doctrina jurídico-administrativa, debido, de una parte, a la discrepancia entre su sentido vulgar y técnico y, de otra, a la diversidad de criterios con que se emplea en el Derecho positivo...» En sentido estricto, para este autor, el concep-

\footnotetext{
17 Miguel SÁnchez Morón, Derecho de la Función Pública, Tecnos, Madrid, 5. a edición, 2008, pág. 67.

18 «O las funciones que tiene por objeto la salvaguardia de los intereses del Estado o de las Administraciones Públicas». EL EBEP deroga expresamente la Ley 17/1993, de 23 de diciembre, sobre incorporación a la función pública española de los nacionales de otros Estados miembros de la Unión Europea.

19 Miguel SÁnchez Morón, Derecho de la Función Pública, Tecnos, Madrid, 4. a edición, 2004, págs. 90 y sigs. La edición de 2008 antes citada se encuentra ya ajustada al EBEP.

20 Los funcionarios de empleo pueden ser eventuales o interinos.
} 
to paradigmático de funcionario se aplica a los de carrera, con las notas de legalidad de nombramiento (no caben los funcionarios de hecho), permanencia (no interinidad ni eventualidad), pertenencia a plantilla de Cuerpo o Escala (lo que no ocurre con el personal laboral) y retribución con cargo a los Presupuestos (lo que deja fuera a los que cobran por arancel) ${ }^{21}$.

\section{Singularidad, menor, en la función pública local.}

No deja de ser característica la reserva limitada de funciones que la Disposición Adicional Segunda de la propia Ley aprobatoria del EBEP mantiene en favor de los funcionarios locales: las que impliquen ejercicio de autoridad ${ }^{22}$, las de fe pública, asesoramiento legal preceptivo, control y fiscalización interna de la gestión económica y presupuestaria, contabilidad y tesorería ${ }^{23}$. Dentro de éstas, corresponde necesariamente en todas las Corporaciones a funcionarios con habilitación estatal las funciones de secretaría (comprensiva de la fe pública y el asesoramiento legal preceptivo) y el control y la fiscalización interna de la gestión económica-financiera y presupuestaria y la contabilidad, tesorería y recaudación ${ }^{24}$. Esta redacción es la misma que ya figuraba en el artículo 92 de la Ley 7/1985, de 2 de abril, Reguladora de las Bases de Régimen Local, ahora derogado, con la particularidad importante de que se ha suprimido la referencia a la previsión de excepcionalidad legal por la que podrían otorgarse las responsabilidades sobre las funciones de contabilidad, tesorería y recaudación a miembros de la Corporación o funcionarios sin habilitación nacional. Como ha señalado SÁNCHEZ MORÓN ${ }^{25}$, una fórmula semejante a la de esta Adicional se contenía en el ahora derogado artículo 92.2 LBRL y fue considerada conforme a la Constitución por la STC 37/2002, de 14 de febrero, lo que «explica, en cierta medida, el mayor porcentaje de personal laboral que existe en la Administración Local». Bien es cierto que el TC se cuestionaba un párrafo que ahora ya no existe, al señalar que

«La duda de constitucionalidad de la Sala proponente se circunscribe al inciso final del precepto transcrito «y, en general, aquellas que, en desarrollo de la presente Ley, se reserven a los funcionarios para la mejor garantía de la objetividad, imparcia-

\footnotetext{
21 Rafael EnTrena Cuesta, Curso de Derecho Administrativo, I, 2, Tecnos, Madrid, 2002 (12. ${ }^{a}$ edición), págs. 260 y sigs. Sobre la exclusión del personal retribuido por arancel, véase lo expresamente señalado en el art. 4. f) del EBEP de 2007.

22 Añeja expresión, un tanto sobrepasada por la realidad, que aún figura, como impeditiva de la gestión indirecta de servicios, en el artículo 251.1 de la Ley 30/2007, de 30 de octubre, de Contratos del Sector Público.

23 Disposición Adicional Segunda, 1.1.

24 Disposición Adicional Segunda, 1.2. Curiosamente, como ya ocurría en la Ley 7/1985, la función de recaudación no aparece dentro de las más amplias atribuciones reservadas, globalmente, a los funcionarios en el número anterior.
}

25 Derecho de la Función Pública cit., edición de 2008, pág. 67. 
lidad e independencia en el ejercicio de la función», el cual entiende que puede ser contrario a la reserva de Ley que establece el art. 103.3 CE, a la luz de la interpretación que de la misma ha hecho el Tribunal Constitucional en la STC 99/1987, de 11 de junio...»

Prosiguiendo el Tribunal:

«...el precepto cuestionado no especifica qué concretas funciones han de ser desempeñadas por personal sujeto al estatuto funcionarial, remitiendo su determinación al desarrollo del mismo. Sin embargo, tal remisión, limitada a la clase de funciones referida, no puede estimarse incondicionada o carente de límites pues en el propio precepto se disponen los criterios o parámetros que han de inspirar en su desarrollo la determinación de las funciones que han de ser desempeñadas por funcionarios públicos, cuales son la garantía de la objetividad, imparcialidad e independencia en el ejercicio de la función pública. Criterios que, aunque genéricos en su formulación, poseen un contenido que es susceptible de ser delimitado en cada caso en concreto en atención a las características de la función o puesto de trabajo del que se trata (...) Hay que concluir, pues, que el art. 92.2 LBRL no vulnera la reserva de Ley que establece el art. 103.3 CE, debiendo ser desestimadas en este extremo las presentes cuestiones de inconstitucionalidad, sin que a tal conclusión pueda oponerse la valoración más positiva que por la Sala proponente le merece la técnica utilizada por el legislador al dar en la Ley 23/1988, de 28 de julio, nueva redacción al art. 15.1 de la Ley 30/1984, de 2 de agosto, que la empleada al redactar el art. 92.2 LBRL, pues el juicio de constitucionalidad no es un juicio de técnica legislativa, ni el Tribunal Constitucional es Juez de la corrección técnica (SSTC 109/1987, de 29 de junio, FJ 3; 341/1993, de 18 de noviembre, FJ 2).»

Pero el legislador ordinario del EBEP sí debió entender que era más correcto técnicamente no utilizar conceptos jurídicos indeterminados o cláusulas residuales con lo que, a la postre, reservó al ámbito funcionarial local un menor número de funciones que en las demás administraciones propiciando, quizá paradójicamente, una mayor presencia de personal laboral.

\section{Funcionarios y estructuras organizativas locales}

La Ley 57/2003, de 16 de diciembre, de Modernización del gobierno local, al introducir un nuevo artículo 85 bis en la ley 7/1985, impuso que en las entidades públicas empresariales locales el secretario del Consejo de Administración ha de ser un funcionario público al que se exija para su ingreso titulación superior y que ejercerá las funciones de fe pública y asesoramiento legal. La misma Ley, a propósito de los municipios de gran población, reserva al «secretario general del Pleno», que ha de ser un funcionario con habilitación estatal y equiparado a los órganos directivos, la redacción y custodia de las actas, la supervisión y autorización de las mismas con el visto bueno del Presidente, al igual que en el caso de la potestad certificante, la asistencia al Presidente, la 
comunicación, publicación y ejecución de los acuerdos y el asesoramiento legal al Pleno y a las comisiones, que será preceptivo cuando lo solicite el Presidente o un tercio de los miembros con antelación suficiente; siempre que se exija para la aprobación de un asunto mayoría cualificada, cuando una ley así lo exija en materia de competencia plenaria y cuando, en las funciones de control y físcalización de los órganos de gobierno, lo solicite el Presidente o la cuarta parte de los concejales (art. 122.5 LBRL). Diversamente, como es sabido, la Secretaría de la Junta de Gobierno Local corresponde a uno de sus miembros que sea concejal, aunque existirá un órgano de apoyo al frente del cual habrá un funcionario con habilitación estatal (art. 126.4 LBRL).

También en los municipios de gran población, sin perjuicio de las funciones reservadas al secretario del Pleno, habrá una asesoría jurídica para asistir al Alcalde cuyo titular, nombrado y separado por la Junta de Gobierno Local, habrá de ser licenciado en Derecho y ostentar la condición de funcionario de administración local con habilitación estatal o funcionario del Estado, de las Comunidades Autónomas o de las entidades locales a los que se exija para su ingreso el grado de doctor o licenciado (art. 129 LBRL).

El titular o titulares del órgano u órganos de gestión económica y presupuestaria (contabilidad, tesorería y recaudación) habrá o habrán de ser funcionarios locales con habilitación estatal, salvo el del órgano que desarrolle funciones de presupuestación (art. 134). Idénticamente, a este tipo de funcionariado le corresponde en exclusiva la función interventora radicada en el órgano responsable del control y la fiscalización interna (art. 136 LBRL).

\section{RECORDATORIO SOBRE LO BÁSICO EN EL ÁMBITO LOCAL}

\section{Situación previa a la Ley 7/2007: principios generales y admisión de excepciones}

Sabido es que la Constitución no otorga expresamente al Estado la competencia para aprobar una ley básica general sobre régimen local. Es cierto que la norma fundamental remite a la ley, genéricamente, «la forma» de materializar la elección de los concejales o las condiciones en que proceda el concejo abierto (art. 140). Pero ni siquiera dice que esa ley haya de ser estatal ${ }^{26}$, por más que, en el primer caso, las elecciones locales se contemplen dentro del

\footnotetext{
26 Como también ocurre con la ley que regule el régimen jurídico de los bienes comunales (art. 132.1 CE). En tal sentido y pese a las actuales previsiones estatales (arts. 79 y 80 LBRL; arts. 75 y 78 TRRL y Reglamento de Bienes de las Entidades Locales, aprobado por Real Decreto 1372/1986, de 13 de junio), el Estatuto de Cataluña, de 19 de julio de 2006, en su art. 160.1.c), declara la competencia exclusiva de la Comunidad Autónoma sobre «el régimen de los bienes de dominio público, comunales y patrimoniales y las modalidades de prestación de los servicios públicos».
} 
«régimen electoral general», reservado por el artículo 81.1 CE a una ley orgánica. Tipo de norma a la que se refiere el artículo 141.1 para hacer factible la alteración de los límites provinciales. En fin, la Constitución también prevé que la ley, sin más precisiones, atribuya funciones a las Corporaciones Locales para las que deberán disponer, en sus Haciendas, de los medios suficientes (art. 142).

Es más: la alusión única a una «legislación sobre Régimen Local» de carácter general y necesariamente estatal, la encontramos en el artículo 148.1.2. ${ }^{\circ}$, donde se contemplan dos supuestos concretos: la asunción estatutaria de las competencias para «las alteraciones de los términos municipales» del territorio de cada Comunidad Autónoma y las funciones, normalmente de cooperación y supervisión, que «correspondan a la Administración del Estado sobre las Comunidades Autónomas y cuya transferencia autorice» a favor de las Comunidades Autónomas la referida «legislación sobre Régimen Local».

Inversamente, en el artículo $149 \mathrm{CE}$, el atinente a las competencias exclusivas del Estado, no hay mención alguna a las entidades locales. De ahí que, una vez más, el artículo 149.1.18. ${ }^{\text {a }}$ se haya convertido en la tabla de salvación del legislador básico, al atribuir al Estado la facultad de dictar «las bases del régimen jurídico de las Administraciones públicas», lo que sin duda concierne a los entes locales, así como «del régimen estatutario de sus funcionarios», al que también se había referido el artículo 103.3 («la ley — por tanto estatal- regulará el estatuto de los funcionarios...»). El artículo 149.1.18. ${ }^{a} \mathrm{CE}$ sigue suministrando argamasa a la construcción de una atribución básica sobre municipios y provincias: la garantía del tratamiento común de los administrados (aquí no se utiliza el término «ciudadanos»), el procedimiento administrativo común, que regirá la praxis cotidiana de Ayuntamientos y Diputaciones, las bases de la contratación y de las concesiones administrativas, que tan de lleno entran en el giro o tráfico peculiar de los entes locales, la legislación expropiatoria, tan conectada al urbanismo y el sistema de responsabilidad patrimonial.

Por tanto parecía claro que de la misma manera que las Comunidades Autónomas iban a ser responsables del mapa local y sus alteraciones y corresponsables de la asistencia y control de municipios y provincias, el Estado regularía el régimen jurídico (en parte en una ley local y, en parte, en una general) de las entidades locales y del personal a su servicio, así como las garantías procedimentales comunes, tanto en la propia ley local como en la de Procedimiento administrativo. Y lo mismo puede decirse de los demás campos citados en el artículo 149.1.18. ${ }^{a} \mathrm{CE}$, a los que hay que unir, como ya se dijo, el régimen electoral y la previsión del concejo abierto, así como la normativa local sobre Haciendas Locales y su consiguiente financiación.

El ámbito del empleo público, con un modelo constitucional preferencialmente estatutario (STC 99/1987 de 11 de junio), es por tanto una de las pilastras con las que el Estado pudo edificar una legislación básica sobre lo local; en la 
Ley 7/1985, de 2 de abril (Título VII), pero también en la Ley 30/1984, de 2 de agosto y en otras disposiciones sectoriales.

Hasta dónde llegaba la potestad reguladora estatal fue cuestión a debatir en doctrina. Como sintetiza MARTín REBOLLO, una de las «interpretaciones limitaba la competencia estatal a la regulación básica de los aspectos vinculados a la relación de servicio, dejando por consiguiente a las Comunidades Autónomas libertad organizativa en orden a la estructuración y modelo de su propia función pública» ${ }^{27}$. Diversamente, otra interpretación, que acogerá el Tribunal Constitucional, no sólo incluirá en la competencia estatal «los aspectos básicos de la situación personal de los funcionarios públicos; es decir de la denominada relación de servicio, contenido indiscutible del régimen estatutario», sino, también, «los aspectos esenciales de la organización de la burocracia de las Administraciones Públicas» (STC 76/1983, de 5 de agosto), por su conexión con «el régimen jurídico» de todas las Administraciones Públicas.

Como es sabido, la STC 76/1983 limita la competencia exclusiva estatutaria «instituciones de autogobierno» a «Asamblea Legislativa, Consejo de Gobierno y Presidente», al entender que «la potestad organizatoria que corresponde a las Comunidades Autónomas para ordenar sus servicios, de los que el personal es uno de sus elementos integrantes, no deriva de la norma estatutaria» cuando se refiere a sus instituciones de autogobierno «sino de la competencia por ellas asumida respecto a la organización de sus propias Administraciones y en esta materia cada Comunidad Autónoma ha de respetar, en cualquier caso, las bases que, de acuerdo con el artículo 149.1.18 ${ }^{a}$ CE corresponde fijar al Estado».

Las SSTC 27/1987, de 27 de febrero; 214/1989, de 21 de diciembre [enjuicia la LBRL] y 109/1998, de 21 de mayo, permiten excepciones a la regla de homogeneidad que acompaña a la regulación básica sobre régimen local, anclada, por cierto, en ese no muy robusto sustento del «régimen jurídico de las Administraciones Públicas». Partiendo de que la «fijación de estas condiciones básicas no pueden implicar en ningún caso el establecimiento de un régimen uniforme para todas las entidades locales de todo el Estado (...) ya que la potestad normativa de las Comunidades Autónomas no es en estos supuestos de carácter reglamentario» (STC 32/1981, FJ 5), «los Estatutos de Autonomía establecen disposiciones específicas en materia de régimen local, atribuyendo a las respectivas Comunidades Autónomas, dentro del marco establecido por la legislación estatal, ciertas competencias en sus relaciones con las entidades locales ubicadas en su territorio» (STC 27/1987, FJ 3, caso Diputaciones valencianas). Pero el régimen general básico - incluido el competencial regulado

27 Luis Martín Rebollo, Leyes Administrativas, 14. ${ }^{\text {a }}$ edición, Thomson-Aranzadi, Cizur Menor, 2008, págs. 1414-1416. Sobre «La extensión de las normas básicas en el nuevo EBEP» y «El EBEP: ¿Hasta dónde llegan las Bases?», véanse las respectivas ponencias de Luis ORTEGA y Federico CASTILLO (en III Congreso de la AEPDA), publicadas en la obra colectiva El control de la legalidad urbanística. El Estatuto Básico del Empleado Público (con Rafael GómEZ-FERRER y Eva DESDENTADo), Instituto Andaluz de Administración Pública, Sevilla, 2009, págs. 221-289. 
de acuerdo al art. 149.1.18. ${ }^{\text {a }} \mathrm{CE}$ - «ha de ser respetado a no ser que, en algún aspecto concreto, su inaplicación resulte expresa e inequívocamente de lo dispuesto en el Estatuto de Autonomía de una determinada Comunidad, como una característica específica de la misma» (STC 27/1987, FJ 9). Es decir: un hecho diferencial estatutario puede desplazar la regulación básica uniforme. Y con más motivo, cuando esa peculiaridad «está fundada» y deriva de un reconocimiento expreso del texto constitucional, caso de la Disposición Adicional 1.a, con respecto a las instituciones forales de los Territorios Históricos. «Se comprende, de este modo, que esa garantía constitucional comporte un tratamiento normativo singular propio de ese régimen local y ello aun frente a los poderes centrales del Estado», titulares de las competencias de regulación básica (STC 214/1989, FJ 26). En resumen, señalará la STC 109/1998, recogiendo la doctrina anterior, «no empece en absoluto a dicha noción [bases como regulación normativa uniforme y de vigencia en toda la Nación] el hecho de que, junto al régimen básico aplicable a la generalidad de las Comunidades Autónomas, coexistan situaciones particulares; aunque, como es palmario, estas excepciones precisan ineludiblemente, bien una expresa habilitación constitucional (...), bien - como sucede en nuestro caso- un específico anclaje estatutario» (FJ 5, tema: Plan Único de Obras y Servicios de Cataluña).

\section{EI EBEP en el contexto de los nuevos Estatutos de Autonomía}

Con independencia de estas excepciones, según la Exposición de Motivos de la Ley 7/2007, de 12 de abril, del Estatuto Básico del Empleado Público,

«...la legislación básica ha de prever los instrumentos que faculten a las diferentes Administraciones para la planificación y ordenación de sus efectivos y la utilización más eficiente de los mismos (...) Esta legislación debe tener en cuenta el amplio proceso de descentralización administrativa que ha tenido lugar durante las últimas décadas. En virtud de él, la Administración General del Estado es, de los tres niveles territoriales de gobierno, la que cuenta en la actualidad con menor número de empleados (...) En paralelo, la emergencia de las Administraciones autonómicas, que hoy cuentan prácticamente con la mitad de los empleados públicos del país, ha hecho aflorar sus propios problemas y necesidades de gestión de personal. Algo semejante puede decirse de las entidades locales, que presentan por lo demás hondas diferencias entre ellas, en las que el número de empleados ha experimentado también un importante crecimiento.

Quiere eso decir que el régimen de la función pública no puede configurarse hoy sobre la base de un sistema homogéneo que tenga como modelo único de referencia a la Administración del Estado. Por el contrario, cada Administración debe poder configurar su propia política de personal, sin merma de los necesarios elementos de cohesión y de los instrumentos de coordinación consiguientes. Por tanto, la densidad de la legislación básica en materia de función pública debe reducirse hoy en día, en comparación con épocas pasadas, teniendo en cuenta en todo caso las determinaciones de los Estatutos de Autonomía y la doctrina establecida por el Tribunal Constitucional». 
Junto al importante reconocimiento de la «propia política de personal» de cada Administración, la mención a los nuevos Estatutos autonómicos tampoco es baladí ya que, en los mismos, no es difícil encontrar referencias expresas y sumamente ambiciosas - tal vez demasiado - a la distribución competencial sobre función pública y, particularmente, sobre el empleo público local, aun cuando se diga salvar el principio de autonomía local. Tal es el caso del Estatuto de Cataluña, aprobado por Ley Orgánica 6/2006, de 19 de julio, cuyo artículo $136^{28}$ establece que

«Corresponde a la Generalitat, en materia de función pública, respetando el principio de autonomía local:

a) La competencia exclusiva sobre el régimen estatutario del personal al servicio de las Administraciones públicas catalanas y sobre la ordenación y la organización de la función pública, salvo lo dispuesto en la letra b).

b) La competencia compartida para el desarrollo de los principios ordenadores del empleo público, sobre la adquisición y pérdida de la condición de funcionario, las situaciones administrativas y los derechos, deberes e incompatibilidades del personal al servicio de las Administraciones públicas.

c) La competencia exclusiva, en materia de personal laboral, para la adaptación de la relación de puestos de trabajo a las necesidades derivadas de la organización administrativa y sobre la formación de este personal».

Similarmente, el artículo 76 del Estatuto de Andalucía ${ }^{29}$ aprobado por Ley Orgánica 2/2007, de 19 de marzo, establece que

«1. En materia de función pública corresponde a la Comunidad Autónoma el desarrollo legislativo y la ejecución en los términos del artículo 149.1.18. ${ }^{\text {a }}$ de la Constitución.

2. Corresponde a la Junta de Andalucía, en materia de función pública y personal al servicio de la Administración, respetando el principio de autonomía local:

a) La competencia exclusiva sobre la planificación, organización general, la formación y la acción social de su función pública en todos los sectores materiales de prestación de los servicios públicos de la Comunidad Autónoma.

b) La competencia compartida sobre el régimen estatutario del personal al servicio de las Administraciones andaluzas.

c) La competencia exclusiva, en materia de personal laboral, sobre la adaptación a las necesidades derivadas de la organización administrativa y sobre la formación de este personal...»

\footnotetext{
28 Al que ya se refiere en su texto preambular el Decreto 195/2008, de 7 de octubre, por el que se regulan determinados aspectos del régimen jurídico del personal funcionario con habilitación de carácter estatal de las entidades locales de Cataluña.

29 En relación con el art. 47.2.1. ${ }^{\mathrm{a}}$ del mismo.
} 
El Estatuto de Aragón, aprobado por Ley Orgánica 5/2007, de 20 de abril, en su artículo 76.13. ${ }^{a}$ tipifica como competencia compartida de la Comunidad el «régimen estatutario de los funcionarios de la Comunidad Autónoma de Aragón y de su Administración Local y las especialidades del personal laboral derivadas de la organización administrativa y la formación de este personal». Previamente, el Estatuto de las Islas Baleares (Ley Orgánica 1/2007, de 28 de febrero), había incluido en su artículo 31, dentro de las competencias de desarrollo legislativo y ejecución el «Estatuto de los funcionarios de la Administración de la Comunidad Autónoma y de la administración local». Diversamente, el pionero Estatuto de la Comunidad Valenciana (aprobado por Ley Orgánica 1/2006, de 10 de abril), en su artículo 50.1 se limita a contemplar el desarrollo legislativo y la ejecución del régimen estatutario de los funcionarios de la Comunidad, sin previsión concreta del personal de otras administraciones. El Estatuto de Castilla y León ${ }^{30}$, pese a su cuidada regulación del régimen local, no hace previsión alguna al funcionariado al referirse, en su artículo 71 a las competencias de desarrollo normativo y de ejecución.

Esta diversidad, relativa, de tratamientos, lleva a la ley estatal 7/2007 a entender que,

«La previsiones de esta Ley son de aplicación a todas las Comunidades Autónomas respetando en todo caso las posiciones singulares en materia de sistema institucional y las competencias exclusivas y compartidas en materia de función pública y de autoorganización que les atribuyen los Estatutos de Autonomía, en el marco de la Constitución» ${ }^{31}$.

El texto alude a la disparidad estatutaria, a las posiciones singulares que pueden primar, como vimos, sobre la homogeneidad básica y, en concreto a competencias «exclusivas y compartidas». Como acabamos de ver lo que en Cataluña es exclusividad «sobre el régimen estatutario del personal» de las Administraciones del territorio, en Andalucía es, más prudentemente, competencia compartida. Lo que parece claro es que la eventualidad de 17 modelos competenciales en la materia conduciría a un caos de administración; a una gestión compleja y a la carta desde el Estado y a una notable inseguridad para los funcionarios, hipotéticamente interesados en la movilidad interterritorial.

\section{Alusión al personal laboral y al de entidades no sometidas al Derecho Administrativo}

Justificando la filosofía ampliatoria de las atribuciones autonómicas, reductora de lo básico y posiblemente correctora, a la baja, de la concepción dual

\footnotetext{
30 Aprobado por Ley Orgánica 14/2007, de 30 de noviembre.

31 Disposición Final Segunda.
} 
que, hasta la fecha, había ofrecido el Tribunal Constitucional ${ }^{32}$ sobre las bases del estatuto funcionarial y el régimen jurídico de todas las Administraciones, la Exposición de Motivos del EBEP, dirá:

«El Estatuto Básico del Empleado Público contiene aquello que es común al conjunto de los funcionarios de todas las Administraciones Públicas, más las normas legales específicas aplicables al personal laboral a su servicio...»

Personal, este último, que pese a la opción preferencial del constituyente por el modelo estatutario (STC 99/1987, de 11 de junio), no puede quedar relegado a unas suma de funciones secundarias precisadas por las leyes ya que, en este punto, quizá contra la ortodoxia del sistema, se ha venido dando - y más, como dijimos, en el ámbito local - un incremento notable de los empleados sujetos al Derecho del Trabajo, favorecido por la aparición o configuración de tareas nuevas y específicas. Por ello, el EBEP, que en este punto parece no ser plenamente consciente de la declaración de exclusividad recogida en diversos Estatutos de Autonomía, afirma que

«Partiendo del principio constitucional de que el régimen general del empleo público en nuestro país es el funcionarial, reconoce e integra la evidencia del papel creciente que en el conjunto de Administraciones Públicas viene desempeñando la contratación de personal conforme a la legislación laboral para el desempeño de determinadas tareas. En ese sentido, el Estatuto sintetiza aquello que diferencia a quienes trabajan en el sector público administrativo, sea cual sea su relación contractual, de quienes lo hacen en el sector privado».

En el intermedio quedan las situaciones a que alude la Disposición Adicional Primera: el personal del sector público estatal, autonómico o local de carácter no administrativo, al que luego nos referiremos. La Ley 7/2007, a diferencia de otras normas de los últimos años, no da su propia versión de lo que comprende la noción de «sector público» ${ }^{33}$ y se limita, por exclusión, a las entidades que « no estén incluidas en el artículo 2 del presente Estatuto y que estén definidas así en su normativa específica».

\section{Alteración de proporciones en los distintos niveles territoriales del empleo público y movilidad}

La Función Pública local ha experimentado, en efecto, un incremento significativo con el desarrollo del Estado de las Autonomías que quizá no se corres-

\footnotetext{
32 Al declarar el propio EBEP, como dijimos, que cada Administración podrá tener «su propia política de personal», aunque tal afirmación, corroborada por los distintos artículos de la Ley, no podrá llevar, por muy diversos condicionantes, a la elección de modelos de filosofía profundamente distinta y prescindir del tradicional de carrera, basado en los Cuerpos y Escalas funcionariales, a favor de un sistema puro de empleo o abierto (Cfr. L. MARTín REBOLlo, Leyes.... cit. págs. 1375-1377).

33 Caso del art. 3 de la Ley 30/2007, de 30 de octubre, de Contratos del Sector Público o del art. 2 de la Ley 47/2003, de 26 de noviembre, General Presupuestaria.
} 
ponde con la recepción de competencias nuevas en virtud del Pacto Local. Recordemos que, en 1986, el año del ingreso de España en lo que hoy es la Unión Europea, nuestro país era el que contaba con un menor porcentaje de funcionarios, entre la población activa, de toda la Comunidad: sólo 12 de cada 100 trabajadores era funcionario. En el otro extremo se hallaba Dinamarca con un $28 \%$ de empleados públicos en el conjunto de los trabajadores. De ese exiguo porcentaje de entonces, a su vez, sólo el $18 \%$ prestaba sus servicios en la Administración Local. En la actualidad, sobre una población que rebasa los 45 millones de habitantes con unos 20e millones de personas empleadas, en España prestan sus servicios casi dos millones seiscientos mil funcionarios y el porcentaje de los que trabajan en los ámbitos locales se ha elevado al 24,12. Los funcionarios estatales, en lógica regresión, suponen el 21,7\%, los de las Comunidades Autónomas el 50,4\% y los universitarios el 3,8\%.

El problema, justamente, radica en la escasa permeabilidad interadministrativa, en lo que el artículo 84 EBEP denomina movilidad voluntaria de las Administraciones:

«Con el fin de lograr un mejor aprovechamiento de los recursos humanos, que garantice la eficacia del servicio que se preste a los ciudadanos, la Administración General del Estado y las Comunidades Autónomas y las Entidades Locales establecerán medidas de movilidad interadministrativa, preferentemente mediante Convenio de Conferencia Sectorial ${ }^{34}$... [órgano que] podrá aprobar los criterios generales a tener en cuenta para llevar a cabo las homologaciones necesarias para hacer posible la movilidad...» ${ }^{35}$

La limitación de la movilidad es un factor de desincentivación de los empleados públicos cuando no de empobrecimiento intelectual, caso de los funcionarios de los Cuerpos universitarios.

\section{ORÍGENES Y EVOLUCIÓN PROPIA DE LA FUNCIÓN PÚBLICA LOCAL}

Sin pretender examinar, ni aún menos revisar, los estudios evolutivos en la materia, sí parece oportuno hacer un breve repaso de algunos de los pasos que, en casi dos siglos, forjaron la andadura y las características actuales de los empleados públicos locales. La importancia de la función pública en el ámbito

\footnotetext{
34 Figura prevista en los arts. 5.5 y 8 de la Ley de Régimen Jurídico de las Administraciones Públicas y del Procedimiento Administrativo Común.

$35 \mathrm{El} \mathrm{n} .^{\circ} 3$ de este art. 84 precisa que «los funcionarios de carrera que obtengan destino en otra Administración Pública a través de los procedimientos de movilidad quedarán respecto de su Administración de origen en la situación administrativa de servicio en otras Administraciones Públicas. En los supuestos de cese o supresión del puesto de trabajo, permanecerán en la Administración de destino, que deberá asignarles un puesto de trabajo conforme a los sistemas de carrera y provisión de puestos vigentes en dicha Administración».
} 
municipal y provincial viene evidenciada por nuestro Derecho histórico más significativo. Así, como nos recuerda Iñaki AGIRREZKUENAGA ${ }^{36}$, ya el artículo 320 de la Constitución de Cádiz, aprobado por unanimidad, se decía que «habrá un secretario en todo Ayuntamiento, elegido por éste a pluralidad absoluta de votos y dotado de los fondos del común». Similarmente, se preveía en el artículo 333 la figura del secretario de la Diputación provincial y previamente, el artículo 321, al desgranar las atribuciones municipales, se refería a «la administración e inversión de los caudales de propios y arbitrios conforme a las leyes y reglamentos, con el cargo de nombrar depositario bajo responsabilidad de los que le nombran».

Inmediatamente, un Decreto de 23 de mayo de 1812, de formación de los Ayuntamientos constitucionales, dispuso el cese de todos los regidores y demás oficios perpetuos (prohibiéndose en el futuro los «asesores con nombramiento y dotación fija»), previéndose ya la figura del secretario municipal, que lo sería también de la Junta de Electores y, poco más tarde, el Decreto de 22 de agosto del mismo año ordenó el cese de «los Escribanos que hasta ahora se han conocido como Escribanos de Ayuntamiento», que serían sustituidos por secretarios elegidos por pluralidad de votos. Previamente, el 10 de julio, un Decreto aclaratorio instado por el Gobernador de la Isla de León, además de referirse al cese de los cargos perpetuos, precisaba que «para ser elegido Secretario de Ayuntamiento, conforme al artículo 320 de la Constitución, no es necesaria la calidad de Escribano». La secretaría municipal se convierte en un puesto de libre elección y remoción por la Corporación, que retribuirá a su titular con cargo a sus fondos, desapareciendo así el régimen arancelario.

El Decreto CCLXIX, de 23 de junio de 1813, aprobando la Instrucción para el gobierno económico-político de las provincias, imponía, no obstante, una cierta tutela de las Diputaciones y, en materia retributiva también del Gobierno, al señalar en su artículo XXI que

«El secretario del Ayuntamiento, que no ha de ser ninguno de sus individuos, a menos que la cortedad del vecindario sea un obstáculo a juicio de la Diputación provincial, podrá ser removido por el Ayuntamiento cuando lo estime conveniente, con el consentimiento de la misma Diputación; y lo que ésta decida sobre el particular, se tendrá por definitivamente resuelto y no se admitirá recurso alguno. Para variar la dotación que por reglamento o costumbre tenga el secretario, deberá el Ayuntamiento obtener la aprobación de la Diputación provincial y después deberá recaer la del Gobierno, sin cuya anuencia no podrá hacerse alteración de este asunto».

Por su parte el Decreto XLV, de 3 de febrero de 1823, con la misma rúbrica del anterior, en los estertores del segundo período liberal, ratificará en su artículo 58 que «corresponde a cada Ayuntamiento la elección de un Secretario a

36 Origen de los funcionarios locales de habilitación estatal: Los cuerpos nacionales, IVAP, Bilbao, 1996, pág. 21. 
pluralidad absoluta de votos y dotado de los fondos del común». Pero se añade algo se sumo interés a efectos de las garantías en la provisión: «Cuando se haya de hacer dicha elección se publicará la vacante, con señalamiento de término, para que puedan concurrir los pretendientes que deberán tener las calidades prevenidas para los demás empleados públicos, prefiriendo en igualdad de circunstancias a los que gocen algún suelo que pueda economizarse a favor del Erario nacional o de otros fondos públicos». La disposición acentúa las facultades, en exclusiva, de la Diputación para aprobar la remoción de los Secretarios «sin lugar a otro recurso superior» ${ }^{37}$ y permite, como luego se dirá, que, transitoriamente, sigan sirviendo como secretarios los antiguos «simples Escribanos numerarios» pero imponiendo incompatibilidad con los que lo fueran de Juzgados.

Este Decreto de 1823 detalla ya las competencias del Secretario (llevanza de libro de acuerdos foliado y sellado, custodia y metódica colocación de los expedientes, autorización de diligencias de carácter económico, firma de acuerdos y encomienda del Registro Civil ${ }^{38}$ ). Igualmente, se señala en el artículo 220 que «el Secretario de los Alcaldes en los asuntos político-gubernativos, es el mismo que el del Ayuntamiento con la dotación que se le señala por este concepto». En fin, el Decreto también se refiere al Depositario en su artículo 41.

Finiquitado el trienio liberal se produce, en el ámbito de la Administración estatal, el «Nuevo arreglo» de los empleados públicos del Reino, aprobado por Real Decreto de 3 de abril de 1828, siendo Ministro de Hacienda Luis López Ballesteros. Disposición a la que alude expresamente, como precedente memorable, la Exposición de Motivos del EBEP. La rudimentaria función pública local y la que servía a los Ministerios seguían caminos paralelos con líneas muy distantes.

Una regulación sistemática, aunque apenas novedosa de la figura del Secretario de Ayuntamiento «nombrado por éste y dotado de los fondos del Común», la hallamos ya en el Real Decreto de 23 de julio de 1835, para el arreglo provisional de los Ayuntamientos del Reino ${ }^{39}$. Disposición que traslada la última facultad para su destitución al Gobernador civil, oída la Diputación. Sistemática que tratará de mejorar la Ley de Ayuntamientos sancionada el 14 de julio de 1840 y mandada publicar reformada el 30 de diciembre de $1843^{40}$, cuyo artícu-

\footnotetext{
37 Art. 59,

38 Art. 7. Véase el Capítulo I de nuestro libro Ayuntamientos, Registro Civil y municipalismo funerario, Iustel, Madrid, 2008 y, en especial, las págs. 26 a 35.

39 Título X, arts. 62 a 67. Para conocer las atribuciones legales y praxis de los fedatarios municipales de la época, es indispensable la consulta del libro de Manuel OrTIZ DE ZúÑIGA, Práctica de Secretarios de Ayuntamientos, Imprenta y Librería de Sanz, Granada, 1843.

40 Título XIII, arts. 84 a 87. Los secretarios no cesarán anualmente, se dice en el artículo 86, ni provocarán vacante salvo por «muerte, imposibilidad, renuncia, incapacidad legal o destitución pronunciada por el propio ayuntamiento», sin tutela alguna.
} 
lo 90 , a propósito del presupuesto municipal, declara obligatorios los gastos de oficina «y pago de sueldos a toda clase de empleados y dependientes que cobren de los fondos del común». Lo que reiterará la Ley de Organización y atribuciones de los Ayuntamientos, de 8 de enero de 1845 en su artículo 93, tras haber introducido, en el artículo 89, la importante garantía de que, para la separación del servicio de un secretario por la Corporación se requería la tramitación de un «expediente en que resulten los motivos de esta providencia» ${ }^{41}$. Igualmente, el Jefe Político, por causa grave, podía suspender a los secretarios dando cuenta al Gobierno para la resolución definitiva «que convenga».

La ley de Ayuntamientos de 5 de julio de 1856, cuatro años después de aprobado en el Estado el recordado Estatuto de Bravo Murillo ${ }^{42}$, regulará detalladamente la figura de Depositarios y agentes de la recaudación ${ }^{43}$, a la vez que exigirá en su artículo 173 que el preceptivo Secretario, pagado con fondos municipales, sea español, mayor de edad y se halle en pleno goce de los derechos civiles y no inhabilitado para los políticos, remitiéndose a una ley especial los estudios o condiciones académicas exigibles.

A propósito de la mayor edad y dando un salto de siglo y medio en el tiempo, cabe recordar cómo el EBEP de 2007, fija en los 16 años la edad de ingreso en la función pública (art. 56.1.c). Esta edad, también conocida por el Derecho Penal y en otras facetas del Derecho Administrativo, es la que pone límite a la enseñanza obligatoria (Ley orgánica 2/2006, de 3 de mayo, de Educación) con lo que es lógico que se facilite el acceso al empleo público y no sólo al privado a partir de la misma. Naturalmente, este precepto no está pensando en los Grupos funcionariales con mayores exigencias de titulación ${ }^{44}$. El tema, en todo caso, no es novedoso ya que, hasta la fijación, mediante Real Decreto-Ley 33/1978, de 16 de noviembre, de la mayoría de edad en los 18 años, no era infrecuente el acceso a funciones públicas de menores de 21 años, de manera paradigmática en los Ejércitos. Como también es sabido, en Derecho Administrativo a los menores de edad se les reconoce, de ordinario, capacidad de obrar ${ }^{45}$, lo que viene a impedir el supuesto grotesco de un funcionario asistido de padre o madre o tutor para pedir un permiso o responder de una falta disciplinaria.

Retrocediendo nuevamente en el tiempo y sin pretensiones de exhaustividad histórica, hallamos la incompatibilidad entre funcionario del municipio o

\footnotetext{
41 Cfr. Iñaki AgIRREZKUENAGA, op. cit. págs. 23 y sigs.

42 Real Decreto de 18 de junio de 1852.

43 Artículos 218 a 221. Diversamente, el Interventor era un regidor (arts. 223 y 226). Sobre la evolución de los Depositarios, véase Alejandro NiETO, «Historia y elegía de los Depositarios de fondos de Administración Local», en Revista de Estudios de la Administración Local y Autonómica n. ${ }^{\circ}$ 234, 1987, págs. 177 y sigs.

44 Véase el art. 76 EBEP.

45 Artículos 30 de la Ley 30/1992, de 26 de noviembre y 18 de la Ley 29/1998, de 13 de julio, Reguladora de la Jurisdicción Contencioso-Administrativa.
} 
la provincia y el cargo de Diputado provincial en la Ley de 25 de septiembre de $1863^{46}$.

La Ley Municipal que se restaura por Decreto de 21 de octubre de 1868, tras la revolución liberal del mes anterior, colocará la regulación de los Secretarios en los artículos 97 a 110 y preverá que las vacantes sean anunciadas por el respectivo Ayuntamiento mediante edictos y en el Boletín Oficial provincial. A la Gaceta del Gobierno debían ir las vacantes de capitales de provincia y localidades de más de mil vecinos. El plazo de solicitud era de un mes (art. 100). Por otro lado, esta ley que incluye un amplio catálogo de supuestos de responsabilidad «de los Ayuntamientos, de sus individuos y agentes», señalará con respecto a Depositarios y Agentes de la recaudación que «son responsables ante el Ayuntamiento; pero éste lo queda, sin embargo, al Municipio civilmente, en caso de insolvencia de aquellos y salvos sus derechos contra los mismos» (art. 144).

La ley Municipal de 20 de agosto de 1870 establecerá una rígida incompatibilidad, incluso para el desempeño interino, entre el cargo de Secretario y los de Concejal, Escribano o Notario, empleados activos de toda clase, contratistas y particulares que tengan compromisos o contratos ${ }^{47}$ municipales, provinciales o estatales (art. 116). Aunque, posteriormente, se decía que la secretaría era compatible con cualquier otro cargo municipal y con sueldo por pensión, retiro o jubilación no superior a 1.250 pesetas al año. La figura funcionarial del Archivero, de no estar dotada o cubierta, sería acumulada a las responsabilidades del Secretario, en tanto que, en la intervención, aparece un contador profesional y sólo, de no existir el mismo en el Ayuntamiento, el Ayuntamiento elegiría a un regidor para tal menester (art. 148). Mientras que la destitución del Secretario exigía la mitad más uno de los votos del Pleno y comunicación del acuerdo al Gobernador civil y a la Diputación, la remoción de Depositarios y Agentes de recaudación era libre (arts.117 y 149). Esa mayoría absoluta para cesar al Secretario se elevó, ya en la Restauración, a dos tercios, en el artículo 124 de la Ley Municipal de 2 de octubre de 1877.

El mismo problema de la exigua retribución que podía esperarse en algunos pueblos, afectaba también a una función próxima y con estrechos parentescos históricos a través de la institución del Registro Civil: la fe pública judicial. Esas estrecheces económicas llevaron al artículo 497 de la Ley orgánica del Poder Judicial, de 15 de septiembre de 1870, a declarar la compatibilidad del cargo de Secretario del Juzgado municipal «con todo empleo y cargo público, cuyo desempeño sea conciliable con él, en las poblaciones que no lleguen a 500 vecinos». Diversamente, por encima de esa población, el puesto era rigurosamente incompatible «con todo empleo, cargo o comisión retribuidos por el Gobierno, por la provincia o por los pueblos».

\footnotetext{
46 Art. $24,10 .^{\circ}$ y $12 .^{\circ}$, que se refiere respectivamente a los empleados públicos en activo servicio y a los que perciban sueldo de los fondos municipales o provinciales.

47 Contratas, servicios y suministros.
} 
De esta última previsión, podría colegirse fácilmente que, en los municipios que no llegaran al medio millar de almas, un funcionario retribuido por el Ayuntamiento - caso paradigmático del Secretario - podría simultanear el Consistorio y el Juzgado con su Registro. Pero la Ley Municipal, de 20 de agosto de 1870 , como acabamos de ver, parecía vedar tal posibilidad al declarar incompatible la Secretaría del Ayuntamiento con la condición de empleado en activo de toda clase, con la excepción de los jubilados que no alcanzaran las referidas 1.250 pesetas anuales ${ }^{48}$.

La filosofía de 1870 es, en gran medida, heredera del constitucionalismo gaditano y ya, en el citado Decreto XLV, de 3 de febrero de 1823, podía leerse en su artículo 61:

«Los Escribanos de los juzgados de partido y los numerarios de los pueblos no podrán ser nombrados Secretarios de Ayuntamiento en lo sucesivo; y con respecto a los que sirven en la actualidad ambos encargos, podrán continuar en ellos los que sean simples Escribanos numerarios de los pueblos; pero los que son Escribanos de los juzgados de partido deberán poner otro que sirvan a la escribanía, o elegirán entre ésta y la Secretaría».

Aún así, volviendo a las previsiones de la legislación de 1870, no encontramos prohibiciones o declaraciones expresas de incompatibilidad hasta unos años más tarde y ya en la Restauración, cuando la modificada Ley Municipal, de 2 de octubre de 1877, había endurecido el régimen de compatibilidades de los Secretarios, prohibiéndoles expresamente el desempeño de cualquier «otro cargo municipal» ${ }^{49}$, aparecen hasta cuatro Reales Órdenes, en menos de tres años, negando la posibilidad de compaginar las secretarías del Juzgado y del Ayuntamiento. La de 10 de marzo de $1881^{50}$, refiriéndose a un funcionario pluriempleado, recordará, que

«La ley no prohíbe que se desempeñen simultáneamente las Secretarías de dos Ayuntamientos, porque no es necesaria semejante prohibición, que nace de la naturaleza misma de las cosas, dada la imposibilidad material de que un individuo cumpla bien a la vez en pueblos distintos las obligaciones anejas al empleo y mucho menos si, como en el caso presente, es también Secretario de los Juzgados municipales: y es que es innecesario para la resolución de este expediente tratar de la incompatibilidad de los cargos de secretario de Ayuntamiento y de Juzgado municipal, ya declarada en las Reales Órdenes de 15 de octubre de 1878, 31 de marzo de 1879 y 28 de octubre de 1880».

Dos décadas más tarde, el Reglamento de Secretarios de Ayuntamiento, aprobado por Real Decreto de 14 de julio de 1905, ratificará, en su artículo 28,

\footnotetext{
48 Artículo 116.

49 Artículo $123.7 .^{\circ}$, in fine.

50 Gaceta del 5 de abril de 1881.
} 
la incompatibilidad entre el cargo de Secretario municipal y los de Notario, Escribano y Secretario de Juzgado ${ }^{51}$. Dicho Reglamento, aprobado tras la suspensión de su homónimo de 8 de agosto de $1902^{52}$ y destinado a los secretarios de municipios de más de dos mil almas ${ }^{53}$, tuvo continuidad en el de 22 de agosto de 1916, reproducción, a su vez, del de 1902. Como ha señalado MARTínEZ MARÍN, años más tarde, la Restauración «reconociendo el fracaso de estos intentos pretorianos contra Ley -formalmente publicados con carácter provisional y suspendidos en sus efectos - se despide de este desafío municipal con un Real Decreto de 21 de junio de $1921{ }^{54}$, limitado a fijar reglas mínimas de dotación, supresión y destitución de los Secretarios ${ }^{55}$.

Huelga señalar que el Estatuto Municipal de Calvo Sotelo, de 8 de marzo de 1924 creó el Cuerpo de Secretarios y supuso «por fin el espaldarazo para los secretarios, una vez vencida su relativa inestabilidad precedente» ${ }^{56}$, en lo que será el inicio de los Cuerpos nacionales, reglamentados, con inclusión de los Interventores, el siguiente 23 de agosto.

Debemos recordar que los funcionarios locales son citados por la Constitución de 9 de diciembre de 1931, en su artículo 41, al declarar la responsabilidad patrimonial subsidiaria del Estado o Corporación al que sirviera el funcionario supuestamente causante de un daño a terceros. Y el artículo 209 de la Ley Municipal de 31 de octubre de 1935, influido por las previsiones de la Constitución de Weimar ${ }^{57}$ de 1919 , precisará que las entidades municipales responderán di-

51 Es del máximo interés el trabajo de Eliseu TOSCAS I SANTAMANS y Ferran AYALA I DOMÉNECH, «Estado liberal y poder local en España. El papel de las incompatibilidades entre empleos públicos en la configuración del moderno secretario municipal: normas y prácticas», Scripta Nova, Revista Electrónica de Geografía y Ciencias Sociales, Universidad de Barcelona, volumen VII, n. ${ }^{\circ} 154,2004$, donde se analizan las incompatibilidades históricas entre el fedatario local y los cargos de concejal, notario y maestro de escuela, con referencias, también, al Derecho italiano.

52 Aprobado «con carácter provisional», a la espera de que, en sesenta días, los Ayuntamientos formularan observaciones o reparos y de que el Consejo de Estado emitiera un informe, que no se produjo, el reglamento se suspendió mediante Real Orden de 23 de diciembre de 1902 (Gaceta del 24 de diciembre). Véase la reconocida monografía de Iñaki AGIRREZKUENAGA, Origen de los funcionarios locales de habilitación estatal: Los cuerpos nacionales, Instituto Vasco de Administración Pública, Oñati, 1996, págs. 38 y sigs. Igualmente, Antonio MARTínEZ MARÍn, Funcionarios locales con habilitación. Pasado, presente y futuro, Tecnos, Madrid, 1999, pág. 70. Una obra clásica, indispensable en la consulta de la evolución seguida por los fedatarios locales, es la de Agustín Bullón RAMíREZ, Historia del Secretariado de la Administración Local, Abella-El Consultor, Madrid, 1968.

53 Cfr. I. AgirReZKuenaga, Origen de los funcionarios locales..., cit., pág. 39.

54 Op.loc. cit.

55 Más tarde, en plena Dictadura de Primo de Rivera, el 23 de agosto de 1924 y vinculado al Estatuto Municipal, de 8 de marzo anterior, un Real Decreto aprobaría el Reglamento de Secretarios e Interventores de fondos.

56 Agirrezkuenaga, op. cit. Pág. 51, en la que cita un conocido texto de Jordana de Pozas.

57 La Constitución del Imperio Alemán, de 11 de agosto de 1919, establecía en su artículo 131 que «si un funcionario, en el ejercicio del poder público que le está encomendado, infringiera sus obligaciones profesionales respecto a una tercera persona, la responsabilidad recaerá primariamente sobre el Estado o la Corporación a cuyo servicio se halle el funcionario, quedando reservada la acción contra éste. No podrá ser excluida la vía judicial ordinaria...» 
recta o subsidiariamente de los daños irrogados por la actuación de sus órganos de gobierno o funcionarios, respectivamente.

Aún la Ley de Régimen Local de 16 de diciembre de 1950, a exactamente cuatro años de la proclamación de la responsabilidad objetiva de la Administración en la Ley de Expropiación Forzosa de 16 de diciembre de 1954, distinguirá entre responsabilidad directa de la Corporación cuando no medie culpa o negligencia grave de Autoridades, funcionarios o agentes y subsidiaria si media la misma.

La Ley de Régimen Local, Texto Articulado y Refundido, aprobado por Decreto de 24 de junio de 1955, ratificó la que ya era clara división entre funcionarios propios de la Corporación y funcionarios de Administración Local con Habilitación Nacional (incluidos los Directores de Banda de Música). Ley que, con la poda introducida por la STC 4/1981, de 2 de febrero y el imprescindible remozamiento derivado de la misma, estuvo sustancialmente vigente hasta la Ley 7/1985, de 2 de abril que vino a ser la norma básica que demandaba el artículo 149.1.18. ${ }^{\text {a }}$ $\mathrm{CE}$ en lo tocante al estatuto de los funcionarios locales pero que, por su objeto, no era obviamente la norma que hubiera de fijar criterios básicos para todos los empleados públicos de las distintas Administraciones. En la práctica, esa función la cumplió, en parte, la Ley 30/1984, de 2 de agosto, de Medidas de Reforma de la Función Pública y la llamada Ley de Funcionarios Civiles del Estado, de 7 de febrero de 1964, a la que la STC 37/2002, de 14 de febrero no atribuyó carácter básico por inferencia natural al no haber sido expresamente declarados como tales sus preceptos por el legislador postconstitucional «ni poder inferirse dicho carácter de su posible consideración como complemento necesario de las normas básicas postconstitucionales». Y ello sin perjuicio de que el Estado ostentara competencia para regular esos contenidos y que la ley pudiera ser aplicada como normativa legítimamente supletoria. A ello habría que añadir que dicha norma de 1964, fue múltiples veces modificada por leyes postconstitucionales con pretensiones de aplicación a todas las Administraciones.

Diversamente, la STC 385/1993, de 23 de diciembre, había entendido que sí tenían carácter básico algunos preceptos sobre personal del Texto Refundido de las disposiciones vigentes en materia de Régimen Local, aprobado por Real Decreto Legislativo 781/1986, de 18 de abril ${ }^{58}$.

\footnotetext{
58 En la que se dice: «Parece correcto concluir que tanto sobre el legislativo como sobre el ejecutivo recae la carga, no una mera posibilidad sino deber, de calificar expresamente las normas que, a su parecer, tengan carácter básico como exigencia del principio de seguridad jurídica. En tal sentido hemos dicho no hace mucho que esa obligación «no sólo pesa sobre el legislador o sobre la Ley votada en Cortes, que es el instrumento normal para la determinación de las normas básicas, sino también, según nuestra reiterada doctrina, sobre el Gobierno de la Nación cuando, con carácter excepcional, pueda hacer uso de su potestad reglamentaria para regular por Decreto alguno de los aspectos básicos de una materia» y con mayor razón, por tanto, «cuando haya de regular mediante un Decreto Legislativo una determinada materia sobre la que el Estado tiene competencia para aprobar las normas básicas». En este último caso, el Gobierno no sólo puede sino que debe establecer qué preceptos tienen naturaleza básica salvo, naturalmente, si se lo impidiera la Ley de delegación o pudiera deducirse que ésta ha pretendido agotar por sí misma la regulación de los as-
} 


\section{LO BÁSICO EN LA FUNCIÓN PÚBLICA LOCAL: UNA REGULACIÓN DISPERSA}

\section{Administración en sentido estricto y sector público local}

En suma, en el momento presente, la regulación básica sobre la función pública local se reparte entre los contenidos del EBEP, la LBRL y, en parte, el TRRL. Todo ello sin perjuicio de las peculiaridades de los cuerpos de policías locales y de alguna previsión singular y esporádica de otras leyes, como la electoral ${ }^{59}$.

El EBEP, aún siendo de aplicación general a las Administraciones de las Entidades Locales, contiene muy escasas referencias específicas al régimen de estas entidades, lo que contrasta con las innumerables referencias o remisiones expresas a las Comunidades Autónomas. Ello se explica, evidentemente, por las potestades legislativas de éstas que, además, podrán detallar la función pública de unos entes locales tradicionalmente concebidos como autonomías meramente administrativas y no políticas. No en balde la reducción en la densidad o intensidad de lo básico, unida a las peculiaridades estatutarias, lleva a dejar una gran parte de la regulación de este campo para las Leyes de función pública de las Comunidades Autónomas, como señala el artículo 6 del EBEP.

Pero autonomía administrativa no significa ya identidad de entes locales con Administración en sentido estricto. La vieja idea corporativa de vecinos gobernados por vecinos elegidos por los propios vecinos se tambalea; muy significativamente en los municipios de gran población, tras la Ley 57/2003, de 16 de diciembre y la intrusión de no concejales en la Junta de Gobierno Local y en otros órganos. El artículo 85 ter y la Disposición Adicional 12 LBRL, que se han incorporado tras la citada Ley 57/2003 han creado un nuevo y más actual marco societario en el ámbito de los entes locales y los organismos públicos de los mismos. Sociedades locales que «se regirán íntegramente, cualquiera que sea su forma jurídica, por el ordenamiento jurídico privado» ${ }^{60}$.

Cuando el artículo 2 EBEP, al precisar su ámbito de aplicación, se refiere «al personal funcionario y en lo que proceda al personal laboral al servicio de (...)

\footnotetext{
pectos básicos de la materia» (STC 179/1992). En definitiva, no necesita el Gobierno una habilitación expresa para tal calificación, que es por tanto posible en cualquiera de las modalidades legiferantes contenidas en el art. 82 de la Constitución y sus límites han de buscarse en la propia delegación legislativa, explícita o implícitamente. Va de suyo, pues, que desde esa perspectiva formal la disposición final séptima, 1 a), del Texto Refundido no ha incurrido en «ultra vires», como tampoco los arts. 129, 145, 150, 158, 160, 410 y 414, a quien se dirige idéntico reproche» (F.J. 3).

59 El artículo 11.4 de la Ley Orgánica 5/1985, de 19 de junio, del Régimen Electoral General, dispone que «los Secretarios de los Ayuntamientos son delegados de las Juntas Electorales de Zona y actúan bajo la estricta dependencia de las mismas».
}

60 Salvo en lo que sea de aplicación la normativa presupuestaria, contable, de control financiero, de control de eficacia o contratación. 
las Administraciones ${ }^{61}$ de las Entidades Locales...» no está incurriendo en redundancia: los municipios, provincias e islas son algo más que Administraciones con personal funcionarial y sometidas al Derecho Administrativo. Son parte del sector público con muy diversas personificaciones en organismos y sociedades $^{62}$; miembros de consorcios y personificaciones mercantiles de capital mixto, de asociaciones; constituyen fundaciones, etc.

La Disposición Adicional Primera del EBEP confirma, a propósito del personal, esta interpretación al señalar que «los principios contenidos en los artículos 52, 53, 54, 55 y 59 serán de aplicación en las entidades del sector público estatal, autonómico y local, que no estén incluidas en el artículo 2 del presente Estatuto y que estén definidas así en su normativa específica». Es decir, hay un sector público local que no puede entenderse incluido en «la Administración» de los entes locales, en el que destacan las personificaciones societarias.

Como recuerda Mercedes FUERTES, corresponde al Pleno, como máximo órgano local con competencias de organización, la competencia para aprobar las creación de sociedades mercantiles, así como su modificación o extinción ${ }^{63}$, observando que «una diferencia hay que tener en cuenta en este régimen municipal, pues si bien con carácter general el acuerdo del Pleno ha de adoptarse con el voto de la mayoría absoluta de los concejales, en los municipios que se hayan acogido al régimen especial calificado de "gran población", será suficiente que la aprobación se realice por mayoría e, incluso, el Pleno puede delegar esta competencia en una comisión» ${ }^{64}$.

La Exposición de Motivos del EBEP, en el difícil calibrado del minimum común imprescindible, señala, con carácter general, como ya vimos desde otra óptica, que

61 Las entidades locales quizá no sean ya, como se ha dicho, «Corporaciones», especialmente desde la Ley $57 / 2003$, en los Municipios de gran población. Son entes territoriales que pueden participar en la creación de otras entidades locales no necesarias, que pueden constituir Administraciones Públicas instrumentales o institucionales y que, por el contrario, no en toda su organización son «Administraciones» ya que pueden formar o participar en la formación de sociedades mercantiles. A ese sector público local no administrativo le son de aplicación los principios contenidos en los artículos a que re refiere la Disposición Adicional Primera.

62 Cfr. Francisco Sosa Wagner, La gestión de los servicios públicos locales, Thomson-Civitas, Cizur

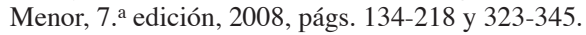

63 Arts. 22.2.f) y 123.1.k) LBRL.

64 Mercedes FuerTes, Grupos públicos de sociedades, Marcial Pons, Madrid, 2007, pág. 123. La facultades de delegación citadas se encuentran en los arts. 47.2.k) y 123. 2 y 3 LBRL. La autora se pregunta si el hecho de que la Ley 57/2003, al importar para las personificaciones gestoras locales el modelo LOFAGE omitiera la facultad del art. 62.f) de la Ley estatal para crear o participar en sociedades cuando ello sea imprescindible para la consecución de los fines asignados, significa «que los organismos públicos locales no pueden ser cabeceras de un grupo d sociedades». A su juicio, este cambio deliberado supone simplemente una afirmación de la reserva ordinaria al Pleno del acuerdo de creación o participación en una entidad mercantil, lo que «no impide la configuración de un grupo público de sociedades». Máxime cuando la reforma de 2003 admite en varias ocasiones la participación accionarial en las sociedades de los organismos públicos locales (pág. 125). 
«la legislación básica ha de prever los instrumentos que faculten a las diferentes Administraciones para la planificación y ordenación de sus efectivos y la utilización más eficiente de los mismos (...) sin impedir que cada Administración pueda configurar su propia política de personal, sin merma de los necesarios elementos de cohesión y de los instrumentos de coordinación consiguientes».

Pero el legislador es consciente de la huida del Derecho administrativo y reconoce que, actualmente, existe «una gradual multiplicación de las formas de gestión de las actividades públicas» en todos los niveles territoriales de gobierno, que persigue ofrecer un servicio diversificado y más eficaz a los ciudadanos. Para ello «la organización burocrática tradicional, creada esencialmente para el ejercicio de potestades públicas en aplicación de las Leyes y reglamentos, se ha fragmentado en una pluralidad de entidades y organismos de muy diverso tipo, dedicadas unas a la prestación de servicios directos a la ciudadanía y otras al ejercicio de renovadas funciones de regulación y control». Esta diversidad de organizaciones ha redundado necesariamente en la heterogeneidad actual de los regímenes de un empleo público lo que, a criterio del legislador, la normativa general básica «no puede constituir un obstáculo ni un factor de rigidez. Antes al contrario, ha de facilitar e impulsar las reformas que sean necesarias para la modernización administrativa en todos los ámbitos». Y aunque a renglón seguido el legislador se refiere a la creciente presencia de personal laboral es obvio que se está refiriendo a la aludida huída del Derecho Administrativo a través de personificaciones no administrativas. Justamente por ello, la Disposición Adicional Primera, a propósito del ámbito específico de aplicación, declarará, como vimos, que, al menos, los principios contenidos en los artículos 52, 53, 54, 55 y 59 (deberes y código de conducta, principios éticos y de conducta, principios rectores de acceso y reserva de cupo a favor de personas con discapacidad) serán de aplicación, también, a las entidades del sector público, incluido expresamente el local, que no tenga el carácter de Administración Pública.

Por tanto y, en resumen, el personal de entidades no administrativas del sector público local deberán desempeñar con diligencia las tareas que tengan asignadas y velar por los intereses generales con observancia de la Constitución y del resto del ordenamiento jurídico, debiendo actuar con arreglo a los principios de objetividad, integridad, neutralidad, responsabilidad, imparcialidad, confidencialidad, dedicación al servicio público (curiosamente, aunque la sociedad no gestione ninguno), transparencia, ejemplaridad, austeridad, accesibilidad, eficacia, honradez, promoción del entorno cultural y medioambiental, y respeto a la igualdad entre mujeres y hombres.

Por su parte, la entidad empleadora deberá reservar en las ofertas de empleo público un cupo no inferior al cinco por ciento de las vacantes para ser cubiertas entre personas con discapacidad, con el objetivo final de alcanzar, progresivamente, el dos por ciento de los efectivos totales de la empresa. Igualmente, deberán respetar en la selección, en general, de su personal, los principios consti- 
tucionales de igualdad, capacidad y mérito y los legales de publicidad de las convocatorias y de sus bases, transparencia, imparcialidad y profesionalidad de los miembros de los órganos de selección, independencia y discrecionalidad técnica en la actuación de éstos, adecuación entre el contenido de los procesos selectivos y las funciones o tareas a desarrollar y agilidad, sin perjuicio de la objetividad, en los procesos de selección.

\section{Ordenación estatutaria y peculiaridades locales}

La Exposición de Motivos del EBEP también afirma que, en «la ordenación del empleo público, así como al sistema de estructuración del mismo en cuerpos, escalas, clases o categorías y a los instrumentos de clasificación de los puestos de trabajo», la nueva regulación - y filosofía - básica, pretende ser escrupulosa con las atribuciones estatutarias de las Comunidades Autónomas, así como con «la autonomía organizativa de éstas y de las Administraciones locales». Para ello, «sobre la base de unos principios y orientaciones muy flexibles, la Ley remite a las Leyes de desarrollo y a los órganos de gobierno correspondientes el conjunto de decisiones que habrán de configurar el empleo público en cada Administración». Se apuesta pues, en esta nueva concepción revisionista y reductora de lo básico, por un cierto modelo propio de empleo público en cada Administración.

La peculiaridad de las entidades locales — haciendo abstracción aún de la presencia necesaria de funcionarios con habilitación de carácter estatal junto a los privativos de la Corporación - , lleva igualmente al legislador de 2007, inmediatamente después de concretar el ámbito de aplicación del Estatuto Básico del Empleado Público, a destinar un artículo - el tercero-, al personal estatutario de las mismas ${ }^{65}$. Dicho precepto, breve, destina su primer número a declarar que el personal funcionario de las entidades locales «se rige por la legislación estatal que resulte de aplicación, de la que forma parte este Estatuto y por la legislación de las Comunidades Autónomas, con respeto a la autonomía local». La competencia estatal básica viene definida en el artículo 149.1.18. ${ }^{\text {a }} \mathrm{CE}$ y la aplicación, como parte que no agota tal regulación, del Estatuto a las Administraciones locales, ya se había afirmado en el artículo 2.1 de la propia Ley 7/2007, de 12 de abril. También la Exposición de Motivos, como se ha destacado, trata, al menos en declaración de principios, de ser respetuosa con la disparidad estatutaria que, a su vez, en todo caso

\footnotetext{
65 Miguel SÁnCHeZ Morón, en Comentarios a la Ley del Estatuto Básico del Empleado Público, por él dirigidos, Lex Nova, Valladolid, 2. a edición, 2008, pág. 69, da cuenta de que el Informe de la Comisión de Expertos creada en el M.A.P. para abordar el proceso de elaboración del Estatuto Básico, recomendaba que las peculiaridades del empleo público en la esfera local se tuvieran en cuenta, sin menoscabo de las garantías generales de acceso e imparcialidad en el ejercicio, en el EBEP. Ello, en razón de la dimensión y variedad de estas entidades y de las funciones que desarrollan. El legislador, como puede apreciarse, sólo atendió muy parcialmente esta recomendación mediante algún precepto aislado, como veremos y alguna modulación en materia de negociación colectiva.
} 
pregona su respeto por la autonomía local reconocida en los artículos 137 y $140 \mathrm{CE}$.

El segundo número del artículo 3 del EBEP prevé la singularidad de los Cuerpos de Policía Local, que se regirán «también por este Estatuto y por la legislación de las Comunidades Autónomas, excepto en lo establecido para ellos en la Ley Orgánica 2/1986, de 13 de marzo, de Fuerzas y Cuerpos de Seguridad»66.

Dicha Ley orgánica, ya preveía, en su artículo 53.3, la aplicación de la Ley 30/1984, de 2 de agosto, a dichos Cuerpos policiales de las entidades locales.

\section{COORDINACIÓN, COLABORACIÓN Y COOPERACIÓN}

En la Exposición de Motivos, con respecto al que será Título VIII, se adelanta que, en el mismo «se establecen los órganos e instrumentos de cooperación entre las Administraciones Públicas que, sin merma de su respectiva autonomía, se consideran esenciales para garantizar la coherencia y comunicación del sistema de empleo público en su conjunto». Se destaca por el legislador la supresión del Consejo Superior de la Función Pública, al reconocer «la escasa operatividad que ha tenido este órgano», pero también «porque las funciones de que fue dotado hace más de veinte años han sido ya sustituidas en la práctica por la actividad de los órganos de coordinación entre el Estado y las Comunidades Autónomas y por las Mesas de Negociación. Como alternativa, en la Conferencia Sectorial de Administración Pública ${ }^{67}$ y en la Comisión de Coordinación del Empleo Público se garantiza la presencia de una representación de la Administración Local, en un reconocimiento cuantitativo a que, «no en vano, integra en la actualidad aproximadamente la cuarta parte de los empleados públicos».

66 El artículo 51.1 de dicha Ley Orgánica dispone que «Los municipios podrán crear cuerpos de policía propios, de acuerdo con lo previsto en la presente ley, en la Ley de Bases de Régimen Local y en la legislación autonómica». En los municipios donde no exista policía municipal, los cometidos de ésta serán ejercidos, según el art. 51.2, por el personal que desempeñe funciones de custodia y vigilancia de bienes, servicios e instalaciones, con la denominación de guardas, vigilantes, agentes, alguaciles o análogos.

El art. 52.1 define a los Cuerpos de Policía Local como «institutos armados, de naturaleza civil con estructura y organización jerarquizada (...) Por lo que respecta al ejercicio de los derechos sindicales, y en atención a la especificidad de las funciones de dichos cuerpos, les será de aplicación la Ley que se dicte en cumplimiento de lo establecido en la disposición adicional segunda, apartado 2, de la Ley Orgánica 11/1985, de 2 de agosto, de Libertad Sindical». En fin, el art. 53.3, adaptado a la regulación de 2003 para los municipios de gran población, prevé que podrán crearse en estos, por el Pleno de la Corporación, Cuerpos de funcionarios para el ejercicio exclusivo de las funciones de ordenar, señalizar y dirigir el tráfico en el casco urbano. En ese caso, dichos funcionarios «no se integrarán en las Fuerzas y Cuerpos de Seguridad, y en el ejercicio de esas funciones tendrán la consideración de agentes de la autoridad, subordinados a los miembros de los respectivos Cuerpos de Policía Local».

67 Se precisa, al respecto que «la mayor autonomía de que cada Administración debe disponer para la ordenación y gestión de su personal, en los términos de este Estatuto, ha de ser complementada por una cooperación más intensa entre todas ellas, al efecto de resolver los numerosos problemas comunes, en beneficio de los ciudadanos y del conjunto de los empleados públicos». 
En esa línea, el artículo 99 EBEP dispondrá que las Administraciones Públicas actuarán y se relacionarán entre sí en las materias objeto del Estatuto de acuerdo con los principios de cooperación y colaboración, si bien con respeto al ejercicio legítimo por las competencias de cada una de ellas.

Como plasmación orgánica de dicha máxima, la Conferencia Sectorial de Administración Pública, sin excluir las atribuciones concretas de otras Conferencias u órganos análogos, se configura como órgano de cooperación general en materia de administración pública entre las Administraciones del Estado, de las Comunidades Autónomas, de las Ciudades de Ceuta y Melilla, y de la Administración Local ${ }^{68}$, que «atenderá en su funcionamiento y organización a lo establecido en la vigente legislación sobre régimen jurídico de las Administraciones Públicas».

Dentro de esta Conferencia Sectorial de Administración Pública, la Ley crea la Comisión de Coordinación del Empleo Público como órgano técnico y de trabajo para hacer efectiva la coordinación de la política de personal entre las distintas Administraciones ${ }^{69}$. Sus integrantes serán los titulares de aquellos órganos directivos de la política de recursos humanos de las Administraciones estatal y de las Administraciones de las Comunidades Autónomas - así como de las Ciudades de Ceuta y Melilla - y los representantes de la Administración Local designados por la Federación Española de Municipios y Provincias ${ }^{70}$.

Debe destacarse que aunque el EBEP hable de los principios de cooperación y colaboración interadministrativa, la Conferencia Sectorial sólo parece atender al primero, tal vez porque la colaboración - aunque imperfecta pues no están presentes necesariamente las Comunidades Autónomas ${ }^{71}$ - se sigue reservando a la Comisión Nacional de Administración Local, definida por el artículo 117 LBRL como el órgano permanente para la colaboración entre la Administración General del Estado y la Administración Local. La Comisión esta formada por un número igual de representantes de las entidades locales y de la

\footnotetext{
68 «Cuyos representantes serán designados por la Federación Española de Municipios y Provincias, como asociación de entidades locales de ámbito estatal con mayor implantación» (art. 100 EBEP).

69 Concretamente, le corresponde impulsar las actuaciones necesarias para garantizar la efectividad de los principios constitucionales en el acceso al empleo público; estudiar y analizar los proyectos de legislación básica en la materia y emitir informe sobre cualquier otro proyecto normativo que las Administraciones Públicas le presenten y, en fin, elaborar estudios e informes sobre el empleo público, que se remitirán a las Organizaciones Sindicales presentes en la Mesa General de Negociación de las Administraciones Públicas.

70 En los términos que se determinen reglamentariamente, previa consulta con las Comunidades Autónomas.

71 A las reuniones de la Comisión podrán acudir representantes autonómicos cuando sean convocados por el Presidente (art. 117.3 LBRL). Tras la reforma operada por Ley 57/2003, de 16 de diciembre, se ha potenciado esta colaboración a tres bandas, al preverse en el nuevo art. 120 bis que «el Estado impulsará la colaboración con las comunidades autónomas con el fin de crear órganos de cooperación conjuntos en materia de régimen local, tanto bajo la forma jurídica de Conferencia Sectorial como de otra naturaleza, de acuerdo con lo dispuesto en el artículo 5 de la Ley 30/1992, de 26 de noviembre, de Régimen Jurídico de las Administraciones Públicas y del procedimiento Administrativo Común».
} 
Administración General del Estado y presidida por el titular del Ministerio de Administraciones Públicas ${ }^{72} \mathrm{Y}$ es que, entre las importantes materias en las que corresponde a la Comisión emitir informe ${ }^{73}$, se encuentran los Anteproyectos de Ley y proyectos de disposiciones administrativas de competencia del Estado en cuanto que afecten a la Administración local, tales como el «régimen estatutario de sus funcionarios ${ }^{74}$.

Otra previsión, más modesta y concreta, en este caso de cooperación, con ribetes tutelares ante la escasez de medios de algunos municipios, la encontramos, a propósito de los Registros de personal y Gestión integrada de recursos humanos, en el artículo 71 EBEP, donde tras ordenar que cada Administración Pública constituya un Registro en el que se inscriban los datos relativos al personal, detallando las peculiaridades de determinados colectivos y, potestativamente, la información agregada sobre los restantes recursos humanos de su respectivo sector público, cuyos contenidos mínimos comunes ${ }^{75}$ se fijarán por Convenio de Conferencia Sectorial ${ }^{76}$, se añade que «cuando las Entidades Locales no cuenten con la suficiente capacidad financiera o técnica, la Administración General del Estado y las Comunidades Autónomas cooperarán con aquéllas a los efectos contemplados en este artículo».

\section{ALGUNAS NOVEDADES TRAÍDAS POR EL EBEP A LA FUNCIÓN PÚBLICA LOCAL}

\section{Estatuto y normativa básica preexistente}

El Estatuto Básico apenas ha incidido en las líneas maestras clasificatorias del personal de las entidades locales de la Ley 7/1985, de 2 de abril, Reguladora de las Bases de Régimen Local ${ }^{77}$, cuyo artículo 89 distingue entre funcionarios de carrera, contratados en régimen de derecho laboral y personal eventual que desempeña puestos de confianza o asesoramiento especial. Partiendo de la

\footnotetext{
72 La designación de los representantes de las entidades locales corresponde en todo caso a la asociación de ámbito estatal con mayor implantación; es decir, a la Federación Española de Municipios y Provincias.

73 En momentos en los que existe un debate político en torno a la disolución de Ayuntamientos, debe recordarse que esta Comisión debe informar previamente en los supuestos en que el Consejo de Ministros acuerde la aplicación de lo dispuesto en el artículo 61 LBRL. La Comisión también puede solicitar de los órganos constitucionalmente legitimados para ello la impugnación ante el Tribunal Constitucional de las Leyes del Estado o de las Comunidades Autónomas que estime lesivas para la autonomía local.

74 Art. 118.1.A).a) LBRL.

75 Así como los criterios que permitan el intercambio homogéneo de la información entre Administraciones.

76 Con respeto a lo establecido en la legislación de protección de datos de carácter personal.

77 Miguel SÁnchez Morón, en Comentarios a la Ley del Estatuto Básico del Empleado Público, cit., pág. 70, destaca que el propio art. 3.1 EBEP prevé que pueda existir otra legislación estatal aplicable al personal de las Administraciones Locales, con lo que dicho Estatuto no tiene por qué agotar — ni agota, ni derogaotras normas estatales, en principio básicas, sobre el empleo público en este ámbito
} 
dualidad funcionarial constituida por los antiguos habilitados de carácter nacional y los empleados propios de la Corporación, el artículo 100 LBRL, declara de competencia de cada Corporación local la selección de estos últimos, aunque reservando a la Administración General del Estado la fijación reglamentaria de las reglas básicas y los programas mínimos a que debe ajustarse el procedimiento de selección y formación de tales funcionarios, así como - en clara conexión con el artículo 149.1.30. ${ }^{\mathrm{a}} \mathrm{CE}-$, los títulos académicos requeridos para tomar parte en las pruebas selectivas, así como los diplomas complementarios expedidos por el Instituto Nacional de Administración Pública o por sus equivalentes autonómicos, que puedan exigirse para participar en las mismas.

El Real Decreto Legislativo 781/1986, de 18 de abril, por el que se aprueba el Texto Refundido de las Disposiciones Legales vigentes en materia de Régimen Local (TRRL), tampoco parece derogado, en modo alguno ${ }^{78}$, cuando, con tintes didácticos, declara que son funcionarios de la Administración Local las personas vinculadas a ella por una relación de servicios profesionales y retribuidos, regulada por el Derecho Administrativo. Y, concretamente, dentro de estos, son funcionarios de carrera los que, en virtud de nombramiento legal, desempeñen servicios de carácter permanente en una Entidad local, figuren en las correspondientes plantillas y perciban sueldos o asignaciones fijas con cargo a las consignaciones de personal del Presupuesto de las Corporaciones. Una definición descriptiva cuyo origen y cimentación doctrinal ya hemos visto.

El mismo Texto Refundido, partiendo de los dos tipos de funcionarios de carrera, prevé que los que no ocupen puestos de trabajo reservados a funcionarios con habilitación de carácter nacional se integrarán en las escalas, subescalas, clases y categorías de cada Corporación, que quedarán agrupadas conforme a la legislación básica del Estado en los grupos que ésta determine, de acuerdo con la titulación exigida para su ingreso. Algo que tampoco se contradice en nada con el artículo 76 EBEP. La cuestión es si, dadas las atribuciones, incluso exclusivas, que algún Estatuto de Autonomía ha incorporado en relación con el régimen estatutario del personal al servicio de las distintas Administraciones públicas de un territorio, cobra más importancia, de cara a las Administraciones Locales, el que el artículo 75.2 EBEP precise, sin que ello sea una gran novedad, que «los cuerpos y escalas de funcionarios se crean, modifican y suprimen por Ley de las Cortes Generales o de las Asambleas Legislativas de las Comunidades Autónomas». Huelga decir que las Corporaciones locales quedan al margen de esta facultad innovadora, dependiendo fundamentalmente de sus Comunidades Autónomas, al carecer de potestad legislativa, por más que, en materias no menos sensibles que la función pública, como son la reserva de Ley en relación con las tasas y precios públicos ${ }^{79}$ o la

\footnotetext{
78 Arts. 130 a 133.

79 Véase la STC 233/1999, de 13 de diciembre (FF.JJ. 10 y 18), en relación con la Ley 39/1988, de 28 de diciembre, de Haciendas Locales y actualmente, el Texto Refundido de la misma, aprobado por Real Decreto Legislativo 2/2004, de 5 de marzo; particularmente sus artículos 12.2 y 15 a 17.
} 
potestad sancionadora ${ }^{80}$, la normativa, una parte de la doctrina y hasta el propio Tribunal Constitucional vengan sublimando el papel y la legitimidad de origen de los Plenos municipales.

Difícilmente puede encontrarse tacha, partiendo de premisas constitucionales, al artículo 133 TRRL cuando declara que el procedimiento de selección de los funcionarios de Administración Local se ajustará a la legislación básica del Estado, sobre función pública. A lo sumo, cabrá añadir que esa legislación básica y los Estatutos de Autonomía, han dado un protagonismo nuevo a las Comunidades Autónomas que, en ningún caso, pueden obviar lo dispuesto en los artículos 23.2, 103.3 y 149.1.18. ${ }^{\mathrm{a}} \mathrm{CE}$. Y aún más pacífica es la aún vigente legislación local del Estado al prever que el régimen selectivo del personal «se establecerá teniendo en cuenta la conexión entre el tipo de pruebas a superar y la adecuación a los puestos de trabajo que se hayan de desempeñar, incluyendo a tal efecto las pruebas prácticas que sean precisas», pues, de forma más precisa, viene a indicar lo mismo que el artículo 55.2.e) del Estatuto Básico de 2007.

El principio recogido en el artículo 134.1 TRRL de que «las convocatorias serán siempre libres», es perfectamente identificable con la expresión «los proce-

80 La aptitud de las ordenanzas para tipificar infracciones y sanciones se contempló ya en los artículos 1.2 y 2.2 del Reglamento del Procedimiento para el ejercicio de la potestad sancionadora, aprobado por Real Decreto 1398/1993, de 4 de agosto, en cuyo Preámbulo, en la línea mantenida por el profesor Alejandro NIETO, puede leerse que, en el ámbito local, las ordenanzas «son el instrumento adecuado (...) para proceder, en el marco de sus competencias a una tipificación de infracciones y sanciones», aunque el Reglamento haya «considerado necesario mantener el referente básico del principio de legalidad, de modo que las prescripciones sancionadoras de las ordenanzas completen y adapten las previsiones contenidas en las correspondientes leyes» y ello sin olvidar «la autorizada línea doctrinal que sostiene que las ordenanzas locales, en tanto que normas dictadas por órganos representativos e la voluntad popular, so el equivalente en el ámbito local a las leyes estatales y autonómicas y tienen fuerza de Ley en dicho ámbito». Posteriormente, la reforma de la Ley Orgánica 1/1992, de 21 de febrero, de Protección de la Seguridad Ciudadana, operada por Ley 10/1999, de 21 de abril, añadió un segundo párrafo al art. 29 para habilitar expresamente a las ordenanzas municipales para especificar los tipos legales de infracciones cuya sanción puede corresponder a los alcaldes. Más tarde la STC 132/2001, de 8 de junio (FJ 6), concluirá que «la exigencia de ley para la tipificación de infracciones y sanciones ha de ser flexible en materias donde, por estar presente el interés local, existe un amplio campo para la regulación municipal y siempre que la regulación local la apruebe el Pleno del Ayuntamiento». Al abrigo de esta última sentencia, se produce la adición a la LBRL por la Ley 57/2003, de 16 de diciembre, de un nuevo Título XI, sobre «Tipificación de las infracciones y sanciones por las entidades locales en determinadas materias» (arts. 139 a 141). Sobre esta cuestión, véase Alejandro NIETO, Derecho Administrativo Sancionador, 5. a edición, Tecnos, Madrid, 2005, págs. 340 y sigs. También, el trabajo «La tipificación de infracciones y sanciones por las Entidades Locales», de Gabriel DOMÉNECH PASCUAL, en Revista General de Derecho Administrativo, n. ${ }^{\circ}$ 6, 2004 y la voz «Ordenanzas municipales (Derecho sancionador)», a cargo de Santiago MuÑoz Machado, en el Diccionario de Derecho Administrativo por él dirigido, Tomo II, iustel, Madrid, 2005, págs. 1744 a 1750. Más recientemente, Alejandro HuERGo LORA, en su Derecho Administrativo Sancionador, iustel, Madrid, 2007, págs. 372 a 377, criticará esta relajación del principio de legalidad, apuntando a la desidia del legislador, particularmente autonómico, para prever y regular espacios que no deberían quedar, sin más, a merced de las ordenanzas locales. Los profesores GARCíA DE ENTERRÍA y TomásRamón FERNÁNDEZ, profundamente críticos con este entendimiento del principio de legalidad, al examinar la redacción de la Ley 57/2003 y advertir que incluye «una descripción básica de las conductas mismas» a precisar y especificar posteriormente por las ordenanzas de cada Ayuntamiento, concluyen que «Isasi se entendiera y aplicara, la nueva regulación podría aceptarse sin grandes escrúpulos», Curso de Derecho Administrativo, II, 11. ${ }^{a}$ edición, Thomson-Civitas, Cizur Menor, 2008, pág. 177. 
sos selectivos tendrán carácter abierto y garantizarán la libre concurrencia», del artículo 61.1 EBEP que, aunque no cuantifica la reserva para la promoción interna, — «hasta un máximo del 50\% de las plazas», puede leerse en el TRRL—, la contempla, así como las medidas de discriminación positiva previstas en la propia Ley $7 / 2007^{81}$. A tal respecto, debe recordarse que ya antes de las ampliaciones competenciales de los Estatutos de Autonomía y de la previsión de leyes territoriales de función pública con contenidos generosos (art. 6 EBEP), era aplicable a las Administraciones Locales, en todo lo no expresamente previsto en la legislación específica, «la reglamentación que para el ingreso en la función pública establezca la respectiva Comunidad Autónoma, y supletoriamente, el Real Decreto 2223/1984, de 19 de diciembre, por el que se aprueba el Reglamento general de ingreso del personal al servicio de la Administración del Estado» ${ }^{82}$.

Aún cuando, por respeto a la libertad terminológica de los legisladores autonómicos, el EBEP se refiera a «oferta de empleo público o instrumento similar» ${ }^{83}$ $\mathrm{y}$ a «relaciones de puestos de trabajo $u$ otros instrumentos organizativos similares» ${ }^{84}$, tal redacción no cambia las expresiones habituales y uniformes contenidas en los artículos 90.2 LBRL $^{85}$ y 130.2 TRRL, o en el artículo 91 LBRL. En cuanto al contenido, será difícilmente sostenible en el futuro, que el Estado se reserve, sin más, «las normas con arreglo a las cuales hayan de confeccionarse las relaciones de puestos de trabajo, la descripción de puestos de trabajo tipo y las condiciones requeridas para su creación», cuando el EBEP se limita a señalar que las Relaciones de Puestos de Trabajo o instrumentos similares serán públicos y comprenderán, al menos, la denominación de los puestos, los grupos de clasificación profesional, los cuerpos o escalas, en su caso, a que estén adscritos, los sistemas de provisión y las retribuciones complementarias. Pero sin concretar nada más, lo que parece lógico, al menos en lo tocante a los cuerpos y escalas y retribuciones complementarias, si se tiene en cuenta que, a las leyes de función pública de las Comunidades Autónomas les corresponde crear y modificar los cuerpos y escalas de funcionarios (art. 75.2 EBEP), lo que parece excluir una redacción tan prolija como la actual del TRRL ${ }^{86}$ y fijar la cuantía y estructura de las

\footnotetext{
81 Sobre las personas con discapacidad, véase el art. 59 del Estatuto.

82 Art. 134.2 TRRL.

83 Art. 70, en sus tres números.

84 Art. 74.

85 «Las Corporaciones locales formarán la relación de todos los puestos de trabajo existentes en su organización, en los términos previstos en la legislación básica sobre función pública.

Corresponde al Estado establecer las normas con arreglo a las cuales hayan de confeccionarse las relaciones de puestos de trabajo, la descripción de puestos de trabajo tipo y las condiciones requeridas para su creación, así como las normas básicas de la carrera administrativa, especialmente por lo que se refiere a la promoción de los funcionarios a niveles y grupos superiores».

86 Arts. 167 a 175. Se detallan no sólo las cinco Subescalas de la Escala de administración general (además afectadas por el art. 76 y la Disposición Transitoria Tercera EBEP), sino las Subescalas Técnica y de Servicios Especiales de la Escala de Administración Especial.
} 
retribuciones complementarias de los funcionarios ${ }^{87}$ (art. 24 EBEP). Huelga recordar, sobre este último aspecto, cómo, tras la plena entrada en vigor del EBEP ${ }^{88}$, las retribuciones básicas se limitarán a sueldo y trienios, lo que aparenta una variación destacable con respecto a lo señalado por el articulo 23.2.c) de la Ley 30/1984, de 2 de agosto, donde se incluían las pagas extraordinarias; precepto al que se venía remitiendo el artículo 153.1 TRRL. No obstante, el artículo 22.2 EBEP, aunque no sustantive este concepto ni precise todos sus ingredientes, declara que, dentro de las retribuciones básicas, «están comprendidos los componentes de sueldo y trienios de las pagas extraordinarias».

Ya nos hemos referido, en el recordatorio histórico, a la novedad de la edad mínima de ingreso en la función pública ${ }^{89}$, que afectará, en la práctica, sólo al nuevo Grupo C2 del artículo 76 del Estatuto, pero, obviamente, afectará a las Administraciones Locales, de la misma manera que las Leyes de Función Pública, en cada Comunidad Autónoma, deberán determinar el régimen de solicitud de la prolongación de la permanencia en el servicio activo hasta los setenta años de edad, como máximo. Parecería lógico que, con respecto a los funcionarios con habilitación estatal fuere la normativa del Estado la que previera el ejercicio de este derecho de prórroga. Posteriormente, será la Administración a la que sirva el funcionario la competente para resolver de forma motivada la aceptación o denegación de la prolongación ${ }^{90}$.

En fin, en el ámbito disciplinario, el TRRL de 1986, dividía drásticamente la tipificación de las faltas ${ }^{91}$, a efectos competenciales, en muy graves que habrían de ser tipificadas por la legislación básica de la función pública ${ }^{92}$ y faltas graves y leves a establecer por la legislación de función pública de la respectiva Comunidad Autónoma, siendo supletoria la legislación de funcionarios civiles del Estado. Aunque la filosofía no ha variado, el EBEP, tras tipificar las faltas muy graves, indica que las graves serán establecidas por Ley de las Cortes Generales o de la Asamblea Legislativa de la correspondiente Comunidad Autónoma o por los convenios colectivos en el caso de personal laboral, atendiendo a las

\footnotetext{
87 Que atenderán, para su fijación, entre otros, a los siguientes factores: La progresión alcanzada por el funcionario dentro del sistema de carrera administrativa; la especial dificultad técnica, responsabilidad, dedicación, incompatibilidad exigible para el desempeño de determinados puestos de trabajo o las condiciones en que se desarrolla el trabajo y el grado de interés, iniciativa o esfuerzo con que el funcionario desempeña su trabajo; el rendimiento o resultados obtenidos y los servicios extraordinarios prestados fuera de la jornada normal de trabajo.

88 La previsión a la que aludimos está en el Capítulo III del Título III y conforme a la Disposición Final Cuarta EBEP, «lo establecido en los Capítulos II [Derecho a la carrera profesional y a la promoción interna y evaluación del desempeño] y III [Derechos retributivos] del Título III, excepto el artículo 25.2 [reconocimiento de trienios por servicios prestados con anterioridad a la entrada en vigor del EBEP], y en el Capítulo III [Provisión de puestos y movilidad] del Título V producirá efectos a partir de la entrada en vigor de las Leyes de Función Pública que se dicten en desarrollo de este Estatuto».

8916 años (art. 56.1.c EBEP).

90 Art. 67.3 EBEP.

91 Art. 147 TRRL.

92 Se recogían en el art. 31 de la Ley 30/1984, de 2 de agosto, de Medidas de Reforma de la Función Pública.
} 
siguientes circunstancias: el grado en que se haya vulnerado la legalidad; la gravedad de los daños causados al interés público, patrimonio o bienes de la Administración o de los ciudadanos y el descrédito para la imagen pública de la Administración. Esas mismas Leyes de desarrollo habrán de determinar, atendiendo a las mismas circunstancias, el régimen aplicable a las faltas leves ${ }^{93}$.

En suma y como ha señalado Ramón SALANUEVA ALCALDE ${ }^{94}$, el estatuto Básico no parece afectar a los preceptos de la LBRL sobre selección y provisión de puestos de trabajo y, en cuanto al TRRL de 1986, habría que entender afectado por el artículo 18 EBEP el artículo 134 sobre requisitos de la promoción interna y, también, a regulación sobre nacionales de otros países (art. 135) $)^{95}$; el artículo 135, al que ya aludimos, en materia de edad mínima de ingreso; el artículo 137, al exigirse ahora expresamente la publicación de los nombramientos ${ }^{96}$ y el artículo 139 sobre la jubilación ${ }^{97}$. Igualmente hay cambios apreciables en la regulación básica de las situaciones administrativas y singularmente en las excedencias y entre las posibles sanciones, el EBEP incorpora ahora el traslado forzoso y el demérito ${ }^{98}$.

\section{Aplicación directa y aplicación inmediata de la nueva legislación a las entidades locales}

Para el autor últimamente citado ${ }^{99}$, a la vista de la Disposición Final Cuarta y del examen detallado del articulado del EBEP puede deducirse que ya son directamente aplicables al personal de las entidades locales:

a) Del Título I, los artículos 1, 3 y 7, sobre el objeto y ámbito de aplicación de la norma.

b) El Título II, sobre las clases de personal, con algunas reservas en cuanto al personal directivo (art. 13), dado que sus funciones directivas profesionales deben ser definidas como tales en las normas de cada Administración y el EBEP encomienda esa concreción no a las normas de desarrollo sino a decisiones gubernativas del Estado y las Comunidades Autónomas, olvidándose, por cierto, de los Consistorios locales ${ }^{100}$.

\footnotetext{
93 Art. 95 EBEP.

94 En la obra colectiva El estatuto Básico del Empleado Público y su desarrollo legislativo, Curso extraordinario dirigido por Venidle BINTANEL GRACIA, Universidad de Zaragoza, 2007, capítulo «Incidencia del EBEP en la normativa de la Administración Local», págs. 88 y 89.

95 Por el art. 57 EBEP.

96 Art. 62.1.b) EBEP.

97 Afectado por los artículos 65 y 67.1.d) EBEP, que prevén la jubilación parcial.

98 Art. 96.1.d) y e).

99 Obra citada en nota 94, págs. 86 y sig.

100 Op. ult. cit., págs. 90 y 91.
} 
c) Del Título III, el capítulo I (derechos); del capítulo III, el artículo 25.2 (trienios de los interinos); el capítulo IV (derecho a la negociación colectiva), que incluye expresamente el reconocimiento de la legitimación negocial de las asociaciones de municipios, así como de las entidades supramunicipales (art. 34.2); el capítulo V (derecho a la jornada de trabajo, vacaciones y permisos, incluidos los motivados por la conciliación de la vida laboral, personal y familiar y por razón de violencia de género y los días de libre disposición por antiguiedad) y el capítulo VI (deberes y código de conducta).

d) El Título IV (adquisición y pérdida de la relación de servicios) aunque a expensas de desarrollo en lo tocante a las condiciones especiales de la jubilación voluntaria y parcial y de prolongación de la relación de servicios hasta los setenta años. Y

e) La Disposición Final tercera (sobre incompatibilidades) $)^{101}$.

También podríamos hablar, con independencia de la vigencia inmediata o mediata, de preceptos del EBEP específicamente referidos al ámbito local (el artículo 2.1, el 3, las Adicionales $1 .^{\mathrm{a}}$ y $2 .^{\mathrm{a}} . .$. ) y de referencias nominales a lo local, aunque insertables en una regulación general (las Mesas de Negociación y el protagonismo de la FEMP ${ }^{102}$, la movilidad funcionarial ${ }^{103}$, la Conferencia Sectorial de Administración Pública ${ }^{104}$ o la situación de servicios especiales ${ }^{105}$, entre otras).

\section{Sobre los funcionarios con habilitación de carácter estatal}

Obviamente, el tema funcionarial local más llamativo, con tratamiento singularizado en la Ley 7/2007, de 12 de abril y un profundo cambio estatutario, es el concerniente a los ahora llamados funcionarios con habilitación de carácter estatal ${ }^{106}$, a los que se dedica, casi íntegramente, la Disposición Adicional Segunda del EBEP.

\footnotetext{
101 Que el autor últimamente citado señala que ha de complementarse por la nueva redacción dada a la Disposición adicional decimoquinta LBRL por la Ley 8/2007, de 28 de mayo, de Suelo.

102 Artículos 33, 34.1 y 36.1 y 3 EBEP.

103 Art. 84.1 EBEP.

104 Art. 100 EBEP.

105 Para cargos electivos, retribuidos y de dedicación exclusiva en las Entidades Locales (art. 87.1.f).

106 Hasta el EBEP denominados «funcionarios con habilitación de carácter nacional». La Ley 7/2007 deroga los artículos 92, 98 y 99 LBRL y los artículos 158 a 166 TRRL, afectando radicalmente a la reglamentación aprobada al respecto por Real Decreto 1174/1987, de 18 de septiembre. El régimen de provisión de las plazas de funcionarios locales con habilitación de carácter nacional ya había sido alterado por Real Decreto 731/1993, de 14 de mayo, a su vez derogado por Real Decreto 1732/1994, de 29 de julio, sobre provisión de puestos de trabajo reservados a Funcionarios de Administración Local con habilitación de carácter nacional. Más modernamente, se aprobó el Real Decreto 834/2003, de 27 de junio, por el que se modifica la normativa reguladora de los sistemas de selección y provisión de los puestos de trabajo reservados a funcionarios de Administración local con habilitación de carácter nacional.
} 
Dicha Disposición, en su número 1.2, comienza, como ya dijimos más atrás, precisando las funciones públicas necesarias en todas las Corporaciones locales y cuya responsabilidad administrativa está reservada a dichos funcionarios con habilitación de carácter estatal, que constituyen una escala con tres subescalas. Estas funciones, en la misma línea de la normativa que se deroga, son las de secretaría, comprensiva de la fe pública y el asesoramiento legal preceptivo y las de control y fiscalización interna de la gestión económico-financiera y presupuestaria, así como las atinentes a contabilidad, tesorería y recaudación.

Como autorizadamente indica Miguel SÁNCHEZ MORÓN ${ }^{107}$, el EBEP «ha mutado sustancialmente la condición de estos funcionarios que ahora son seleccionados por cada Comunidad Autónoma ${ }^{108}$ », a las que igualmente corresponde «regular ahora las bases de los concursos ordinarios» ${ }^{109}$, aunque haya también un concurso unitario anual ${ }^{110}$ que, con carácter supletorio y un tanto residual, convoca el MAP ${ }^{111}$.

\section{Derecho de la Función Pública, cit., págs. 76 y sig.}

108 La creación, clasificación y supresión de puestos de trabajo reservados a funcionarios con habilitación de carácter estatal corresponderá a cada Comunidad Autónoma, de acuerdo con los criterios básicos que se establezcan por Ley. La convocatoria de la oferta de empleo, con el objetivo de cubrir las vacantes existentes de las plazas correspondientes a estos funcionarios, corresponde igualmente a las Comunidades Autónomas, así como su selección, conforme a los títulos académicos requeridos y programas mínimos aprobados reglamentariamente por el Ministerio de Administraciones Públicas. Las Comunidades Autónomas publicarán las convocatorias de las pruebas selectivas de los funcionarios con habilitación de carácter estatal en sus Diarios Oficiales y las remitirán al Ministerio de Administraciones Públicas para su publicación en el Boletín Oficial del Estado.

109 El artículo 16 del Decreto 195/2008, de 7 de octubre, por el que se regulan determinados aspectos del régimen jurídico del personal funcionario con habilitación de carácter estatal de las entidades locales de Cataluña, regula la Puntuación en los concursos. Sobre un total de 100 puntos, la puntuación máxima de méritos generales será de 20 puntos. El departamento de Gobernación y Administraciones Públicas fijará el baremo de méritos relacionados con el conocimiento de la organización territorial autonómica y el derecho propio, hasta 40 puntos. Las entidades locales podrán incluir méritos específicos hasta un total de 40 puntos en relación con las características y las funciones del puesto de trabajo. 2. Los municipios en los que figuren puestos reservados a funcionarios con habilitación de carácter estatal de categoría superior a las relaciones de puesto de trabajo podrán establecer una puntuación mínima para la adjudicación de las vacantes. Esta puntuación mínima en ningún caso será superior al $25 \%$ de la puntuación total.

110 El EBEP distingue, en efecto, entre dos concursos anuales: el concurso ordinario y el concurso unitario. Las Comunidades Autónomas en su ámbito territorial regularán las bases comunes del concurso ordinario así como el porcentaje de puntuación que corresponda a cada uno de los méritos (generales, de organización peculiar y derecho propio, lengua cooficial y los específicos relacionados con las características del puesto). Las Corporaciones locales aprobarán el concurso ordinario anual con inclusión de las plazas vacantes que estimen necesario convocar, así como sus convocatorias, que remitirán a la correspondiente Comunidad Autónoma para su publicación. Las resoluciones de los concursos se efectuarán por las Corporaciones Locales y las remitirán a la respectiva Comunidad Autónoma quien, previa coordinación de las mismas para evitar la pluralidad simultánea de adjudicaciones a favor de un mismo concursante, proceda a su publicación en su Diario Oficial, dando traslado de la misma al Ministerio de Administraciones Públicas para su publicación en el Boletín Oficial del Estado y para su inclusión en el registro de funcionarios con habilitación de carácter estatal.

Por su parte, el Ministerio de Administraciones Públicas efectuará, supletoriamente, en función de los méritos generales y los de valoración autonómica y de acuerdo con lo establecido por las Comunidades Autónomas respecto del requisito de la lengua, la convocatoria anual de ámbito estatal de un concurso unitario de los puestos de trabajo vacantes, reservados a estos funcionarios con habilitación de carácter estatal que deban proveerse por concurso, en los términos que establezca reglamentariamente el propio Ministerio de Administraciones Públicas.

111 Por Resolución de 29 de octubre de 2008, de la Dirección General de Cooperación Local del MAP (BOE del 20 de noviembre de 2008), se convocó concurso unitario de provisión de puestos de trabajo reservados a funcionarios con habilitación de carácter estatal 
Excepcionalmente, para los municipios de gran población previstos en el artículo 121 LBRL así como para las Diputaciones Provinciales, Cabildos y Consejos Insulares, podrán cubrirse por el sistema de libre designación, entre funcionarios con habilitación de carácter estatal de la subescala y categoría correspondientes, los puestos a ellos reservados que se determinen en las relaciones de puestos de trabajo en los términos previstos en la legislación básica sobre función pública. Esta previsión del EBEP, cuyo origen está en la Ley 10/1993, de 21 de abril ${ }^{112}$, es ciertamente contradictoria «con las funciones de control y fe pública que realizan estos funcionarios y con las estrictas garantías de imparcialidad que es preciso acordarles» ${ }^{113}$. No hay que olvidar, en una justa crítica a las modificaciones legales de los últimos años, que estos Cuerpos «nacieron para controlar desde dentro la legalidad de la actuación de los electos locales», por lo que las reformas «no benefician precisamente el ejercicio independiente, responsable y eficaz de esta labor» ${ }^{114}$.

Igualmente, corresponde a partir de ahora a las Comunidades Autónomas efectuar, de acuerdo con su normativa, los nombramientos provisionales de funcionarios con habilitación de carácter estatal, así como las comisiones de servicios, acumulaciones, nombramientos de personal interino ${ }^{115} \mathrm{y}$ de personal accidental.

Pensando aún en la tradicional movilidad de estos funcionarios, que posiblemente se resienta en el futuro, el régimen disciplinario aplicable a los mismos se regulará por lo dispuesto por cada Comunidad Autónoma ${ }^{116}$, pero correspondiendo al Ministerio de Administraciones Públicas la resolución de los expedientes disciplinarios en los que el funcionario se encuentre ya destinado en otra Comunidad distinta a aquélla en la que se le incoó el expediente.

En suma, asistiremos paulatinamente a una sustitución de la normativa reglamentaria del Estado por las disposiciones de las Comunidades Autónomas, salvo en aquellos puntos en que la propia Disposición Adicional Segunda mantiene competencias ejecutivas en la Administración estatal ${ }^{117}$.

\footnotetext{
112 Como ya se ha dicho, este sistema fue declarado constitucional por la STC 235/2000, de 5 de octubre.

113 M. SÁNCHEZ MoRón, Derecho de la Función..., cit., págs. 76 y sig.

114 Ibidem. M. SÁNCHEZ MORÓN añade que la situación que se persigue con estas alteraciones estatutarias «sólo se explica por el predominio de los intereses de los partidos políticos y sus bases locales y (...) reduce las garantías de control de unas entidades locales que, en el momento presente, no están sobradas de controles de legalidad precisamente».

115 La Ley 42/1994, de 30 de diciembre, permitió, en su artículo 64 el nombramiento con carácter interino de los habilitados nacionales por razones de necesidad o urgencia; supuestos que debieran precisarse al máximo para no incurrir en excesos o, incluso, en fraude de ley.

116 También se regirán por los sistemas de acceso, carrera, provisión de puestos y agrupación de funcionarios aplicables en su correspondiente Comunidad Autónoma, respetando las reglas básicas establecidas en el EBEP.

117 Como resume M. SÁNCHEZ Morón en Comentarios a la Ley del Estatuto Básico..., cit., pág. 75. Es el caso de Cataluña, donde ya se ha expedido el Decreto 195/2008, de 7 de octubre, por el que se regulan deter-
} 
Queda por saber si esta nueva forma de habilitación mucho más autonómi$\mathrm{ca}^{118}$ que estatal, si exceptuamos el temario mínimo y el registro funcionarial, va a traducirse en una merma de la imparcialidad e independencia de unos empleados llamados, desde hace casi un siglo, a defender la legalidad y a fiscalizar internamente fondos y cuentas públicas ${ }^{119}$. El acierto o desacierto del legislador, en tiempos en los que la crisis económica ha dejado aún más al desnudo las flaquezas municipales, es algo más que una cuestión corporativa de Secretarios o Interventores.

minados aspectos del régimen jurídico del personal funcionario con habilitación de carácter estatal de las entidades locales de dicha Comunidad Autónoma.

118 El proyecto de Ley remitido a las Cortes calificaba de autonómicos a estos funcionarios, en un cambio confesado que quedó más encubierto tras la tramitación parlamentaria.

119 M. SÁNCHEZ MoRÓN (op. ult. cit. pág. 74), recuerda cómo el Informe de la Comisión de Expertos creada en el MAP para abordar el proceso de elaboración del Estatuto Básico, era partidario de regular este funcionariado en la legislación de régimen local y no en el EBEP por sus peculiaridades y porque las funciones de control interno, profesional e independiente que desarrollan, difícilmente pueden garantizarse en las pequeñas entidades locales, «si no es por medio de funcionarios de carrera dotados de un estatuto que proteja su imparcialidad». 